2013s-25

\title{
Nowcasting GDP: Electronic Payments, Data Vintages and the Timing of Data Releases
}

John W. Galbraith, Greg Tkacz

Série Scientifique
Scientific Series

Montréal

Août 2013

(C) 2013 John W. Galbraith, Greg Tkacz. Tous droits réservés. All rights reserved. Reproduction partielle permise avec citation du document source, incluant la notice $\mathbb{C}$.

Short sections may be quoted without explicit permission, if full credit, including (C) notice, is given to the source.
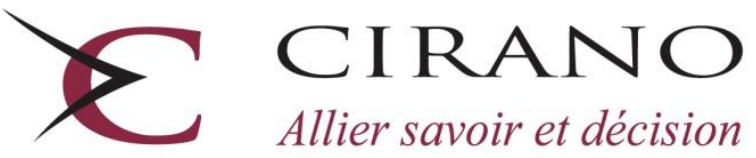

Allier savoir et décision

Centre interuniversitaire de recherche en analyse des organisations 


\section{CIRANO}

Le CIRANO est un organisme sans but lucratif constitué en vertu de la Loi des compagnies du Québec. Le financement de son infrastructure et de ses activités de recherche provient des cotisations de ses organisations-membres, d'une subvention d'infrastructure du Ministère du Développement économique et régional et de la Recherche, de même que des subventions et mandats obtenus par ses équipes de recherche.

CIRANO is a private non-profit organization incorporated under the Québec Companies Act. Its infrastructure and research activities are funded through fees paid by member organizations, an infrastructure grant from the Ministère du Développement économique et régional et de la Recherche, and grants and research mandates obtained by its research teams.

\section{Les partenaires du CIRANO}

\section{Partenaire majeur}

Ministère de l'Enseignement supérieur, de la Recherche, de la Science et de la Technologie

Partenaires corporatifs

Autorité des marchés financiers

Banque de développement du Canada

Banque du Canada

Banque Laurentienne du Canada

Banque Nationale du Canada

Banque Scotia

Bell Canada

BMO Groupe financier

Caisse de dépôt et placement du Québec

Fédération des caisses Desjardins du Québec

Financière Sun Life, Québec

Gaz Métro

Hydro-Québec

Industrie Canada

Investissements PSP

Ministère des Finances et de l'Économie

Power Corporation du Canada

Rio Tinto Alcan

State Street Global Advisors

Transat A.T.

Ville de Montréal

\section{Partenaires universitaires}

École Polytechnique de Montréal

École de technologie supérieure (ÉTS)

HEC Montréal

Institut national de la recherche scientifique (INRS)

McGill University

Université Concordia

Université de Montréal

Université de Sherbrooke

Université du Québec

Université du Québec à Montréal

Université Laval

Le CIRANO collabore avec de nombreux centres et chaires de recherche universitaires dont on peut consulter la liste sur son site web.

Les cahiers de la série scientifique (CS) visent à rendre accessibles des résultats de recherche effectuée au CIRANO afin de susciter échanges et commentaires. Ces cahiers sont écrits dans le style des publications scientifiques. Les idées et les opinions émises sont sous l'unique responsabilité des auteurs et ne représentent pas nécessairement les positions du CIRANO ou de ses partenaires.

This paper presents research carried out at CIRANO and aims at encouraging discussion and comment. The observations and viewpoints expressed are the sole responsibility of the authors. They do not necessarily represent positions of CIRANO or its partners. 


\title{
Nowcasting GDP: \\ Electronic Payments, Data Vintages and the Timing of Data Releases
}

\author{
John W. Galbraith ${ }^{\dagger}$ Greg Tkacz
}

\begin{abstract}
Résumé / Abstract
We describe and assess the usefulness of a newly-constructed database of electronic payments, comprised of debit and credit card transactions as well cheques that clear through the banking system, as indicators of current GDP growth. Apart from capturing a broad range of spending activity, these variables are available on a very timely basis, thereby making them suitable candidate indicators. Controlling both for the release dates of various variables and the vintage of GDP available to analysts at the time a nowcast is produced, we generate nowcasts of GDP growth for a given quarter over a span of five months, which is the period over which interest in nowcasts would exist. We find that nowcast errors fall by about 60 per cent between the first and final nowcast. Evidence on the value of the additional payments variables is mixed, however; the point estimates suggest reductions in forecast loss at some nowcast horizons, but with considerable variability.
\end{abstract}

Mots clés/Keywords : GDP; nowcasting; electronic payments.

Codes JEL : E32, E37, C53

\footnotetext{
* Thanks to the Social Sciences and Humanities Research Council of Canada (SSHRC) for financial support of this research and to CIRANO for research facilities. Thanks also to seminar participants at Dalhousie, Mount Allison and Queen's Universities, as well as at the Bank of Canada workshop on "Nowcasting and Short-Term Forecasting", the annual meeting of the Canadian Economics Association and the International Symposium on Forecasting for comments on earlier drafts of this paper. We are also grateful to the Interac Organization, the Canadian Payments Association and the Canadian Bankers' Association for providing us the electronic payments data, and to Matthew Meland for research assistance

$\dagger$ Department Department of Economics, McGill University and CIRANO.

$¥$ Corresponding author. Department of Economics, St. Francis Xavier University and CIRANO, gtkacz@stfx.ca
} 


\section{Introduction}

Observing the current pace of economic activity is crucial to policy-makers and other decision makers as it can affect, for example, the implementation of counter-cyclical policies or near-term production decisions. However, the most important measure of economic activity, GDP growth, is released with a two-month lag and is subject to substantial revision. For this reason, policy-makers require reliable nowcasts (i.e., current-period estimates) of GDP growth in order to monitor economic conditions.

The literature on nowcasting has evolved rapidly in the last few years, although it has a long history, beginning with the work of Mitchell and Burns (1938), who classified hundreds of variables as leading, coincident or lagging indicators. This NBER-type study on indicators was regularly updated for the next thirty years, but then waned around the seventies. Stock and Watson $(1989,1991)$ subsequently renewed interest in coincident indicators via the construction of simple indexes. More recent studies (e.g. Nunes (2005), Camacho and Perez-Quiros (2008)) have focused on the construction of models primarily for very short-term forecasting, while others (e.g. Andreou, Ghysels and Kourtellos (2010)) have focused on methodological contributions aimed at improving the incorporation of variables measured at different frequencies within a single model. A related strand of literature aims at constructing high-frequency indexes capable of capturing turning points in the business cycle in a timely manner (e.g. Aruoba, Diebold and Scotti (2009)).

The main contribution of the present study is in investigating a broadening of the information set at the disposal of nowcasters. We have compiled, and examine the utility of, a database on the payments system in Canada, providing us with information on the values and volumes of debit and credit card transactions, as well as of cheques that clear through the banking system. Apart from providing new proxies for household and business spending, these data have the benefit of being compiled electronically, thereby being available on a timely basis, as well as being virtually free of measurement error. 
The data on debit and chequing transactions were constructed by aggregating the various payments that clear through the members of the Canadian Payments Association (CPA) on a daily basis. With the payments data being organized by transactions between the different CPA members, and also by type of payment and by region, each monthly observation on debit or chequing transactions that we computed required aggregating the information in a 120,000-row spreadsheet. Meanwhile, credit card transactions were obtained from the Canadian Bankers' Association, which aggregates Visa and MasterCard transactions on a monthly basis.

Several previous studies have used electronic payments data on a limited basis, usually within an empirical industrial organization context (e.g. Shankar and Bolton 2004), while others have used scanner data to understand price movements (e.g. Silver and Heravi 2001, Burstein, Eichenbaum and Rebelo 2005). However, to our knowledge, a study using such a broad range of payments data to nowcast GDP growth has not been undertaken for any country.

Methodologically, this study follows Giannone, Reichlin and Small (2008) in that we track GDP nowcast improvements over time. Specifically, we assess the marginal contribution of payments data over a five-month span, which extends from the first day of a quarter until the month of the data's eventual release. The prima facie evidence suggests that payments data typically lower nowcast errors, but the degree of reduction is variable and, in the small sample sizes inevitable in dealing with quarterly GDP data, there is not sufficient power to obtain any statistically significant reduction.

Nonetheless, it is noteworthy that even relatively small nowcast errors can generate negative publicity for policy makers. For example, the following quotation appeared in the financial press on Monday, June 4, 2012, following the release of 2012Q1 GDP growth on Friday, June 1: 
On Friday, we learned that the Canadian economy grew just 1.9 per cent at an annual pace in the first quarter, making a mockery of the Bank of Canada's forecast of 2.5 per cent growth. Indeed, markets appear to be enjoying a good chuckle at the expense of the Bank of Canada these days. The yield on the Government of Canada 10-year bond fell below 1.62 per cent last week, marking its lowest level since at least 1950. The threat of rate hikes usually sends bond yields higher, not lower. ${ }^{1}$

The context of the above quotation is that the Bank had begun hinting at a rate increase with the release of its April Monetary Policy Report. Economic momentum appeared to be picking up, given that it revised its forecast for 2012Q1 GDP growth up to 2.5 per cent on 18 April, 2012, from 1.8 per cent, which had been its forecast for 2012Q1 published on 18 January, 2012. Consequently, although the Bank appeared to be preparing markets for rate increases, it later appeared that markets were dictating that the policy rate should instead fall.

This recent example illustrates several points: (1) Policy credibility can be gained or lost with nowcasts; (2) nowcasts can have an impact on expected policy decisions, and thus bond yields; (3) nowcasts for a given quarter can evolve over time, sometimes substantially; and (4) a lot of emphasis is placed on the accuracy of a nowcast relative to the first release of GDP growth, even though it is well known that GDP growth is subsequently revised. ${ }^{2}$

The present paper will track nowcasts produced at different points in time for a given quarter, and demonstrate how nowcast performance varies with updated data, and whether electronic payments can contribute to improving nowcast performance, while taking into consideration revisions to monthly GDP growth.

\footnotetext{
${ }^{1}$ Berman, D. (2012) "Rate Hikes? Rate Cuts More Likely." The Globe and Mail, June 4, 2012.

${ }^{2}$ We find that the mean absolute revision to annualized quarterly GDP growth in Canada from 2005 to 2009 is 0.63 percentage points, so the 0.60 percentage point deviation between the Bank's nowcast and the initial release for 2012Q1 could eventually simply be explained by a subsequent upward revision of GDP growth by Statistics Canada.
} 
In the next section we describe the payments data that, as we noted above, are being used for the first time in this context, as well as the variables used in our base-case model. In Section 3 we present the model used for our GDP nowcasting exercise, which accounts for the release dates of our various indicators. In Section 4 we conduct our nowcasting exercise on Canadian GDP growth, while Section 5 concludes.

\section{Data}

\subsection{Payments Data}

In the last fifteen years Canadians have increasingly adopted cashless means of payment. They are among the world's most intensive users of debit cards, with more than 100 transactions per person per year, while credit cards account for about 25 percent of all transactions in the economy, roughly equivalent to the percentage of transactions using cash. Although cheques account for less than 1\% of all transactions, the average value of small (under $\$ 50,000$ ) cheques that clear through the payments system is over $\$ 1,100$, reflecting the fact that they are used for large infrequent transactions, such as rent payments, tuition fees, income and property taxes, or the purchase of big-ticket items such as automobiles.

These transactions are recorded, and the aggregated values are available rapidly. The corresponding payments system variables, which we have compiled at a monthly frequency from January 2000 through December 2009, are the following:

1. Debit: we capture point-of-sale (POS) payments that clear between two institutions. This involves a debit from the consumer's bank account and a credit to the merchant's account. This captures more than 80 percent of all debit card transactions in the economy, with a national average of more than 100 transactions per second, 24 hours per day. We aggregate all debit 
transactions for the members of the Canadian Payments Association (CPA), who graciously provided the data. We have data on both the aggregate value and volume of all debit transactions.

2. Credit: Visa and MasterCard dominate the Canadian credit card market, accounting for about 90 percent of all credit card transactions in the economy. These cards are issued by Canadian banks. We aggregate the monthly value of all combined Visa and MasterCard transactions. These data were obtained from the Canadian Bankers Association (CBA).

3. Cheques: as with debit cards, we capture all small cheques that clear between banks. We choose to focus on cheques valued under $\$ 50,000$, as these would often be used for payments of goods and services, whereas larger-valued cheques are typically used for financial transactions, which are less relevant for an analysis of GDP movements. These data were obtained from the CPA.

As a general rule, debit cards are used for small- to medium-sized transactions, and average about $\$ 48$ per transaction; credit cards are typically used for larger purchases, and average about $\$ 110$; and cheques, while infrequently used, average over $\$ 1,100$. In Figure 1a we plot the average values of all three payment types from 2000 to 2009 . We observe that each has regular seasonal peaks, and that cheques and credit transactions tend to have a greater upward trend than average debit transactions. Business-day payments system data are reported only for Monday through Friday, excluding also public holidays. As a result, weekend and holiday transactions must be recorded with the data of a weekday, typically but not invariably Tuesday. In aggregating as we do to a monthly frequency, however, this limitation is of no effect.

The CPA data record both value and volume of transactions for debit, small cheque and large cheques. The ability to compare value and volume gives additional insight into the interpretation of the data presented above; Figures $1 \mathrm{~b}-1 \mathrm{~d}$ describe the joint distributions of volume and average value for each of the three means of payment. 
Each of the Figures 1b-1d plots a joint density of volume of transactions per business day, and average value per transaction (colour represents height according to the usual convention; the density is estimated by kernel methods with bandwidth chosen by cross-validation). The data plotted are residuals from a simple quadratic trend model with a dummy variable for days on which aggregated weekend or holiday transactions are reported.

The three means of payment display quite different patterns. For debit purchases, higher volume of transactions is clearly associated with higher average value per transaction; this may reflect larger volume and average value around holidays, for example. For small cheques, there is some negative association, although there appears to be little association in the most concentrated region. For large cheques, there is very little association between average value and volume (most of the probability mass is approximately parallel to the volume axis). Of course, the degree of association between value and volume affects the potential value of including both in a forecasting equation.

Since we are interested in nowcasting GDP growth, we will also have to study the growth rates of these series. The annualized growth rate of any payments variable $x_{t}$ is computed over $k$ quarters as:

$$
\dot{x}_{t}=\log \left(\frac{x_{t}}{x_{t-k}}\right) \times \frac{400}{k}
$$

In Figures $2 \mathrm{a}$ and $2 \mathrm{~b}$ we plot, respectively, the quarter-over-quarter $(k=1)$ and the year-over-year $(k=4)$ annualized growth rates of these three series. We plot both since we are interested in both quarterly and annual GDP growth, and so will require a different transformation of the payments variables for each growth rate studied. Figure 2a reveals the strong seasonal patterns of these payments data. Interestingly, the peaks and troughs of these data occur in different periods. Specifically, cheques tend to peak in Q3, debit cards in Q4 and credit cards in Q4 or Q1. Although we make 
no attempt in this paper to model the choice of payments instrument by consumers, Galbraith and Tkacz (2013) found that daily debit card transactions accelerated in both value and volume during the four weeks prior to Christmas; with bank accounts depleted during the holidays, households may therefore increasingly rely on credit cards while they rebuild their savings in Q1. Meanwhile, cheques may be peaking in Q3 to reflect infrequent transactions that occur that quarter, such as property tax or tuition payments. Regardless of the exact causes, having all three payments types at our disposal allows us to control for any substitution effects between these payments methods, thereby allowing us to isolate better the impact of these variables on GDP growth. For example, a consumer choosing to switch to a credit card from a debit card for grocery purchases would result in a growth in credit card transactions and a fall in debit transactions. For this reason, using any series in isolation could lead to false signals about economic activity, whereas using all of them in a model would endogenize a consumer's choice of payment technology, thereby providing better signals about economic activity.

However, if households display "payments inertia" and infrequently switch between payments methods, then having all payments methods in a model will not necessarily produce better nowcasts, as some payments methods may display more sensitivity to economic conditions than others. For instance, debit card transactions may fall more rapidly than credit card transactions during a recession, as the former cannot be used once savings are depleted, while the latter may still be used even if savings are zero and one's job has been lost. As a result, determining which to include in a model is an empirical question, and so we will consider various payments methods combinations in our nowcasting exercise.

The year-over-year growth rates (Figure 2b) are smoother, and reveal a clearer picture of the business cycle. The recession of 2008-09 appears as sharp drops in all three payments variables, while the slowdown in 2001Q3 (which met the technical definition of a recession in the United States but was only a single quarter of negative growth in Canada) is clearly visible, and also reveals a slowdown in the growth of 
average payments. In that period, which includes the attacks of $9 / 11$, we observe that both average debit and credit transactions showed negative growth rates.

To control for seasonal effects, we seasonally adjust our payments data using the X11-ARIMA process, which is the same used for adjusting GDP in the National Accounts. In Section 4 we repeatedly seasonally adjust the payments data as we update our sample through the out-of-sample nowcasting exercise in order to ensure that we replicate the data that would have been available to analysts in the past. However, for exposition purposes we present in Figures $3 \mathrm{a}$ and $3 \mathrm{~b}$ the nonseasonally-adjusted (NSA) and seasonally-adjusted (SA) quarterly and year-overyear growth rates of credit card values. In Figure 3a we observe that many of the wide credit card fluctuations are largely due to seasonal factors, as the adjusted series is much smoother. In Figure $3 b$ the original series shows virtually no seasonal features. This follows from the manner in which this series is constructed, as it compares the level in the current quarter to that of the similar quarter one year prior. In our empirical work we will be using the SA series for nowcasting both quarterly and annual GDP growth, although for the latter case there is little difference between SA and NSA data.

A notable payments technology absent from our list of payments methods is cash, and this follows for two reasons. First, all our models incorporate the growth of narrow money, which is one component of the Composite Leading Index, which we use as a control variable and discuss further below. Second, cash is most often used for "small" transactions, and so cash purchases would be least correlated with aggregate spending fluctuations, which are most affected by consumer spending decisions on larger discretionary items. According to Arango, Huynh and Sabetti (2011), debit and credit cards account for about $89 \%$ of the value of retail transactions above $\$ 50$, while cash is used for the remaining $11 \%$. Cash is most widely used for transactions under $\$ 15$, with $59 \%$ of the value of all such transactions being made using cash. By contrast cheques are almost never used for retail purchases in Canada, although as mentioned above they capture large, 
infrequent payments that could crowd out discretionary purchases made using debit and credit, and so are worth retaining for this purpose.

\subsection{Basecase Indicators}

Although a visual inspection of Figure $2 \mathrm{~b}$ leads one to suspect that payments variables are correlated with the business cycle, more careful scrutiny suggests that we need to assess the information content of these variables relative to indicators that are already regularly compiled and monitored. In other words, we need to assess whether they provide any new information at the margin.

Apart from lagged GDP growth, we experimented with several candidate variables ${ }^{3}$ that could be useful for nowcasting, but only one was retained, as it helped achieve the lowest nowcast errors, was available on a timely basis, and already captures movements in several other variables. The Composite Leading Index (CLI), is constructed by Statistics Canada as a simple average of ten different variables that capture movements in the business cycle from various sectors, and standardized such that its mean and standard deviation correspond to that of GDP growth. The ten variables that comprise the CLI are:

Group 1: Leading Indicators

- Housing index (housing starts and MLS housing sales)

- Business and personal services employment

- TSX stock index

- Narrow money supply (real)

- U.S. CLI

Group 2: Manufacturing

- Average work week (hours)

\footnotetext{
${ }^{3} \mathrm{We}$ considered the unemployment rate, various interest rates and interest rate spreads, stock prices, and the exchange rate. Many of these variables proved useful for longer-term forecasts, but were not as useful for nowcasting purposes.
} 
- New orders, durables

- Shipments/inventories of finished goods

Group 3: Retail Trade

- Furniture and appliance sales

- Other durable goods sales

Once all the data are compiled, the CLI for a given month $t$ is released around the third week of month $t+1$.

The key benefits of the CLI are that (1) this variable captures movements in a broad range of sectors in a single number; and (2) it is released in a relatively timely manner. However, within the CLI some of the components are measured with a lag, as they rely on survey data. This is the case for the Retail Trade variables, as well as new orders of durables and shipments/inventories of finished goods in the Manufacturing group; for the CLI of a given month $t$, data for these components actually reflect observations for month $t$-2. In addition, the U.S. CLI would reflect month $t-1$.

When using the CLI in our nowcasting equations we convert it to either quarterly or year-over-year growth rates and plot these growth rates in Figures $4 \mathrm{a}$ and $4 \mathrm{~b}$. We observe that the CLI also tends to follow a pattern that would correspond to the business cycle of the last ten years, picking up in particular the recession of 2008-09 and the slowdown of 2001.

The remainder of this study is concerned with studying whether payments variables add any relevant information that is not already captured by the CLI and lagged GDP growth. However, to make fair comparisons we need to ensure that the relevant base case model only incorporates information available at the time a nowcast is made. As new information accrues over time, the models would then incorporate the new data, and presumably the nowcasts would be converging to the "true" GDP growth rate. In 
the next section we explain how we account for revisions to GDP growth, update our models over time, and what data are available at each point in time.

\subsection{Monthly GDP Growth}

Our interest lies in nowcasting quarterly GDP growth, as this is the headline number around which major policy decisions and announcements are made. For example, the Bank of Canada's Fixed Announcement Dates (FADs) are timed such that policy rate decisions take into account recent GDP numbers. The quarterly release also reflects complete updates to the income and expenditure accounts as GDP components are updated at this time as well.

In between the quarterly National Accounts, Statistics Canada also releases estimates of GDP by industry on a monthly basis, so this is a variable that can serve as an important input into any quarterly nowcast. The quarterly number is simply an average of the monthly numbers, so having knowledge of the growth rates of the first two months of a quarter implies that two-thirds of a quarter is already known. However, the monthly numbers are only released two months after the end of a given month, so care must be taken when performing the GDP nowcasting exercise to ensure that one uses only GDP observations that are actually available.

Apart from timeliness, as with quarterly GDP growth, the monthly observations are also subject to revision. Tkacz (2010) found that year-over-year GDP growth in Canada was revised on average by 0.25 percentage points. This number is not overly large by international standards, but it is also not negligible. As a result, when using monthly GDP to nowcast quarterly GDP it is important to use the vintage that would have been available at the time a nowcast would have been produced.

No public sources of real-time monthly Canadian GDP exist, so we constructed our own using historical issues of Statistics Canada publications (Catalogue Number 15001X). In Figures 5a and 5b we plot the first and "final" (i.e. the 2009Q4) vintages of 
quarterly and annual GDP growth rates. From Figure 5a we observe that revisions tend to make peaks higher and troughs deeper, with the trough of the recession in 2009Q1 being revised down by almost a full percentage point. Note that the firstrelease and "final" observations are the same in 2009Q4, since the first release of the 2009Q4 vintage was of course not yet revised at that time. In our out-of-sample forecast horizon (2005 to 2009), the mean absolute revision for quarterly GDP growth between the first-release and the 2009Q4 GDP vintage is 0.63 percentage points, while for year-over-year GDP growth it is 0.23 percentage points.

Given the disparities between the first and final releases, we can compute GDP nowcast errors for either of these two series, as there would be some interest in both. However, we expect nowcasts to be more accurate for the first-release data, as nowcasts would be conditional on first-release data. Furthermore policy decisions are often based, and credibility gauged, on recently released data. For this reason our RMSEs will be computed using the first-release data as the series to be nowcast. In the Appendix we present some analogous results in which the final release of GDP is the variable to be nowcast.

\section{Nowcasting Equations and the Timing of Data Releases}

From the discussion in Section 2, we can write

$$
y=f(\text { lagged } y, C L I, P A Y)
$$

where $y$ is output growth; CLI the growth rate of the Composite Leading Index; PAY is a vector of payments variables, which may include the value and volume of debit, credit and chequing transactions.

The functional relationship may take various forms. We consider models that aggregate information from the various predictors via OLS regression, model 
averaging methods which combine results from numerous models having different regressors (Hansen 2007), and dimension reduction methods which use principal components of a regressor matrix and compare all information sets on a common number of regressors (see Galbraith and Hodgson 2012 for an exposition of the latter two classes of method). Because the results from the different methods were qualitatively similar, we report here only the simplest least-squares forecast results.

Growth rates are computed as quarter-over-quarter or year-over-year, and we present results for each case. Our "base case" model omits the payments variables; we then consider five alternative models which respectively contain (i) the growth rates of the value and volume of debit card transactions; (ii) the growth rates of the value and volume of credit card transactions; (iii) the growth rates of the value and volume of cheque transactions; (iv) the growth rates of the value and volume of debit and credit transactions; and (v) the growth rates of the values and volumes of debit cards, credit cards and cheques.

We have omitted from (2) time subscripts, as these would vary according to the precise time at which an analyst would be required to generate a nowcast. However, for estimation and nowcasting purposes we need to specify the appropriate datings. In what follows we assume that one is required to generate a nowcast of GDP growth for quarter $t$. The first nowcast is generated on the first day of the quarter, and a new nowcast is generated on the first day of each subsequent month until the official growth rate is released, which would be at the end of the second month of quarter $t+1$.

For example, the third quarter of a year occurs in the months of July, August and September, and the actual growth rate for Q3 would be released around November 30. Thus, an analyst would produce a nowcast for Q3 on July $1^{\text {st }}$, August $1^{\text {st }}$, September $1^{\text {st }}$ October $1^{\text {st }}$ and November $1^{\text {st }}$, for a total of five nowcasts. We would expect that as time passes and new data become available, the nowcast will become more precise as its production date is closer to the actual release date. With five 
different nowcast production dates, and with new monthly data becoming available for each one, the time subscripts on the explanatory variables in (2) would vary for each production point within the quarter.

The release dates for GDP and the CLI are regular and known in advance. GDP is always released two months after a given month, and the CLI around the third week after a given month.

Since payments data are recorded electronically, they are in principle available at a daily frequency, and released the next business day. For example, the Interac Organization studies daily movements in debit card transactions, and regularly compares year-over-year growth rates for transactions on specific days. Galbraith and Tkacz (2013) in fact use daily debit transactions to assess the impact of extreme events, such as 9/11 and the SARS pandemic, on economic activity. Similarly, credit card companies precisely track their daily transactions, and often issue press releases in the days leading up to Christmas to pinpoint the busiest transaction day of the year. For this reason, should the demand exist, payments data for a given month $t$ can be available on the first day of month $t+1$, making these data extremely timely relative to other spending indicators.

Given the release dates above, we can specify the five variants of (2) that an analyst can estimate for each of the five different nowcasting points for a given quarter $t$. These time subscript specifications are provided in Table 1 , and to facilitate the discussion we provide an illustration using $t=\mathrm{Q} 3$. Superscripts denote the particular vintage of GDP growth that is known at each point in time.

In each case we use whatever quarterly data is available. The monthly data is incorporated into the nowcast by using the available monthly data to compute average observations for the incomplete quarter. For example, when a nowcast is generated on July $1^{\text {st }}$, an analyst would have CLI data for May. The growth rate of these variables for April and May relative to January and February (i.e the first two 
months of Q1) is used as a proxy growth rate for these variables for Q2. The more data available for a quarter, the closer our estimate of the final value for that quarter, and therefore the more accurate our nowcast.

\section{Nowcasting Canadian GDP Growth}

Our full sample begins in 2000Q1 and ends in 2009Q4, for a total of 40 quarterly observations. In our nowcasting exercise we use the first 20 observations for initial estimation of parameters, which are then used to produce a nowcast for 2005Q1. The sample is updated by one quarter, parameters are re-estimated and a nowcast produced for 2005Q2. This process is repeated until we obtain nowcasts for 2009Q4.

Given the different time subscripts associated with the variables in Table 1, we treat each of the five specifications as a different model, and so we track the nowcasting performance of each specification over the full nowcasting sample. For example, for the specification in which a nowcast is produced during the first month of each quarter, we track the accuracy of nowcasts produced on January $1^{\text {st }}$, April $1^{\text {st }}$, July $1^{\text {st }}$ and October $1^{\text {st }}$ i.e. the first month of each quarter. The next specification uses the data available at the beginning of the second month, and so a new set of nowcasts is produced on February $1^{\text {st }}$, May $1^{\text {st }}$, August $1^{\text {st }}$ and November $1^{\text {st. }}$ We repeat this for each of the five periods for which a nowcast for quarter $t$ is required, as discussed in Section 3.

In Figures $6 \mathrm{a}$ and $6 \mathrm{~b}$ we plot the nowcasts of quarterly and year-over-year GDP growth using the basecase model (i.e. without the payments variables), using the data available at the beginning of each month. We can visually observe that the nowcasts produced at the beginning of the quarter (i.e. the $1^{\text {st }}$ month) are the least accurate. Notably, they miss many of the turning points in GDP growth, and miss the timing of the recession that began in 2008Q4. However, as more data become available during the quarter, we see that the nowcasts approach actual GDP growth. By the $5^{\text {th }}$ month a nowcast for GDP growth is produced with knowledge of the 
growth rates for the first two months of the quarter, so it is easier to nowcast the full quarter.

Interestingly, it appears that by around the fourth nowcast of the quarter analysts should be able to predict the turning points in GDP growth. For example, the trough in GDP growth was accurately captured as 2009Q1, so by July 2009 (the fourth month of 2009Q2), analysts should have been predicting an improvement in economic activity using the basecase model. Meanwhile, the nowcasts produced in the first two months do not appear to capture many turning points; only when lagged quarterly GDP growth appears in the information set (month 3) does some ability to pick up turning points appear.

In Figures $7 \mathrm{a}$ and $7 \mathrm{~b}$ we plot a new set of nowcasts generated by the model augmenteded with debit card transactions (both values and volumes). As with Figures $6 \mathrm{a}$ and $6 \mathrm{~b}$ we notice the improvements in nowcasting accuracy that accrue over time, with those generated in the $1^{\text {st }}$ month being least accurate, and those generated in the $5^{\text {th }}$ month being most accurate. However, it is not clear by visually comparing Figures 6 and 7 whether the payments variables contribute to lowering nowcast errors in a substantial manner. For this purpose we can study the root mean squared (nowcast) errors (RMSEs), which are presented in Figures $8 \mathrm{a}$ and $8 \mathrm{~b}$.

These graphs plot the RMSEs produced by the six different specifications at five different points in time. As previously discussed, we assume that the series we are attempting to nowcast accurately is the first release of GDP growth; results using the final GDP vintage may be found in the Appendix.

The base case RMSEs are denoted in black, with a diamond denoting the precise values. Series below this line show improvements in nowcast accuracy. We see that the base case RMSE drops from about 2.5 at month 1 to 1.0 in months 4 and 5. The largest marginal improvements occur between Months 2 and 3 (when lagged 
quarterly GDP growth first enters the information set) and Months 3 and 4 (when the first monthly GDP observation for the quarter being nowcast is observed).

Payments variables tend show lower RMSE for the first two months, and also at month 5. These improvements can be more clearly seen in Figures 9a and 9b. Largest improvements involve lowering the RMSE by at most 20 per cent, and for quarterly GDP growth this is achieved with the presence of debit card transactions in the model. For the year-over-year growth rate, the largest improvement occurs at month 5 , i.e. notable improvements in accuracy occur in the month immediately preceding the release of the observation being nowcast.

It is the nature of GDP forecasting, or nowcasting, that there are few observations, implying little statistical power to discriminate among rival models. Here, the out-ofsample period includes only 20 observations. ${ }^{4}$ It is not possible to establish that any of the point differences are statistically significant. However, given that this sample contains the sharpest quarterly drop in economic activity ever observed in Canada, the observed improvements in nowcasting accuracy do suggest the possibility that payments variables could be of use in detecting downturns more rapidly.

\section{Conclusion}

Nowcasts matter for many decision-makers, and the present study documents the degree to which the accuracy of nowcasts varies with the amount of information available to an analyst: in these data the average nowcast error is approximately 60 per cent lower if produced just prior to a data release (month 5) compared with one produced at the beginning of a quarter (month 1 ).

We assess how electronic payments, which are available on a timely basis, can contribute to producing nowcasts. We find some evidence of improvement in

\footnotetext{
${ }^{4}$ A forecast-encompassing test for nested models with data subject to revision, such as that of Clark and McCracken (2009), could be performed, but results are unlikely to be statistically significant for such a small sample.
} 
nowcast accuracy when payments variables, particularly debit card payments, are included in a model, especially when nowcasts are produced early or late in a quarter. This suggests that the marginal contributions of such variables vary over a quarter: they contain different amounts of information relative to other publicly available data, at different points in time.

A desirable further development of this research would be to combine electronic transactions with other data that can be measured with some accuracy at a daily frequency, and a framework can be established that would automate the generation of nowcasts on a daily basis as new data is observed. In this context we can also find more effective methods for combining data at different frequencies within a single model. The state space approach used by Armah (2011) could be one avenue worth pursuing, as could a MIDAS mixed-frequency regression approach (e.g. Andreou, Ghysels and Kourtellos (2010)). 


\section{References}

Andreou, E., E. Ghysels and A. Kourtellos (2010) "Regression Models with Mixed Sampling Frequencies." Journal of Econometrics 158, 246-261.

Arango, C., K. Huynh and L. Sabetti (2011) "How Do You Pay? The Role of Incentives at the Point-of-Sale." Working Paper 2011-23, Bank of Canada.

Armah, N. (2011) “Predictive Densities and State Space Nowcasting." Working Paper, Bank of Canada.

Aruoba, S. B., F. X. Diebold and C. Scotti (2009) "Real-Time Measurement of Business Conditions." Journal of Business and Economic Statistics 27, 417-427.

Burstein, A., M. Eichenbaum, and S. Rebelo (2005) "Large Devaluations and the Real Exchange Rate." Journal of Political Economy 113, 742-784.

Camacho, M. and G. Perez-Quiros (2008) "Introducing the Euro-STING: Short-Term Indicator of Euro-Area Growth.” Working Paper, Bank of Spain.

Clark, T.E. and M.W. McCracken (2009) "Tests of Equal Predictive Ability with RealTime Data." Journal of Business and Economic Statistics 27, 441-454.

Galbraith, J.W. and D. Hodgson (2012) "Dimension reduction and model averaging for estimation of artists' age-valuation profiles.” European Economic Review 56, 422-435.

Galbraith, J. W. and G. Tkacz (2013) "Analyzing Economic Effects of September 11 and Other Extreme Events using Debit and Payments System Data." Canadian Public Policy 39, 119-134.

Giannone, D., L. Reichlin and D. Small (2008) "Nowcasting: The Real-Time Informational Content of Macroeconomic Data." Journal of Monetary Economics 55, 665-676.

Hansen, B. (2007) “Least squares model averaging." Econometrica 75, 1175-1189.

Mitchell, W. C. and A. F. Burns (1938) "Statistical Indicators of Cyclical Revivals." In Moore, G. H. (Ed.) Business Cycle Indicators, Vol. 1. Princeton: Princeton University Press, 184-260, Reprinted 1961.

Nunes, L. C. (2005) "Nowcasting Quarterly GDP Growth in a Monthly Coincident Indicator Model." Journal of Forecasting 24, 575-592. 
Shankar, V. and R. N. Bolton (2001) "An Empirical Analysis of Determinants of Retailer Pricing Strategy." Marketing Science 23, 28-49.

Silver, M. and S. Heravi (2001) "Scanner Data and the Measurement of Inflation." The Economic Journal 111, F383-F404.

Stock, J. and M. W. Watson (1989) "New Indexes of Coincident and Leading Economic Indicators." NBER Macroeconomics Annual 1989, 351-394.

Stock, J. and M. W. Watson (1991) "A Probability Model of the Coincident Economic Indicators." In Leading Economic Indicators: New Approaches and Forecasting Records, Lahiri, K. and Moore, G.H. (eds) Cambridge: Cambridge University Press, 6385.

Tkacz, G. (2010) “An Uncertain Past: Data Revisions and Monetary Policy in Canada." Bank of Canada Review, Spring, 41-51. 
Table 1: Data Release Dates and Nowcasting Equation Specifications

\begin{tabular}{|c|c|c|c|}
\hline Quarter $t$ & Available Data & Example: $t=Q 3$ & Available Data \\
\hline \multirow[t]{2}{*}{$1^{\text {st }}$ Month } & $\begin{array}{l}\text { Quarterly: } \\
y_{t-2}^{(2)}, C L I_{t-2}, P A Y_{t-1}\end{array}$ & \multirow[t]{2}{*}{ July $1^{\text {st }}$} & $\begin{array}{l}\text { Quarterly: } \\
\text { GDP (Q1), CLI (Q1), u (Q1), } \\
\text { PAY (Q2) }\end{array}$ \\
\hline & $\begin{array}{l}\text { Monthly: } \\
y_{\frac{1}{3}(t-1)}^{(1)}, C L I_{\frac{2}{3}(t-1)}\end{array}$ & & $\begin{array}{l}\text { Monthly: } \\
\text { GDP (April), CLI (May), u } \\
\text { (May) }\end{array}$ \\
\hline \multirow[t]{2}{*}{$2^{\text {nd }}$ Month } & $\begin{array}{l}\text { Quarterly: } \\
y_{t-2}^{(3)}, C L I_{t-1}, P A Y_{t-1}\end{array}$ & \multirow[t]{2}{*}{ August $1^{\text {st }}$} & $\begin{array}{l}\text { Quarterly: } \\
\text { GDP (Q1), CLI (Q2), u (Q2), } \\
\text { PAY (Q2) }\end{array}$ \\
\hline & $\begin{array}{l}\text { Monthly: } \\
y_{\frac{2}{3}(t-1)}^{(1)}, P A Y_{\frac{1}{3}(t)}\end{array}$ & & $\begin{array}{l}\text { Monthly: } \\
\text { GDP (May), Pay (July) }\end{array}$ \\
\hline \multirow[t]{2}{*}{$3^{\text {rd }}$ Month } & $\begin{array}{l}\text { Quarterly: } \\
y_{t-1}^{(1)}, C L I_{t-1}, P A Y_{t-1}\end{array}$ & \multirow[t]{2}{*}{ September $1^{\text {st }}$} & $\begin{array}{l}\text { Quarterly: } \\
\text { GDP (Q2), CLI (Q2), u (Q2), } \\
\text { PAY (Q2) }\end{array}$ \\
\hline & $\begin{array}{l}\text { Monthly: } \\
C L I_{\frac{1}{3}(t)}, P A Y_{\frac{2}{3}(t)}\end{array}$ & & $\begin{array}{l}\text { Monthly: } \\
\text { CLI (July), u (July), PAY } \\
\text { (August) }\end{array}$ \\
\hline \multirow[t]{2}{*}{$4^{\text {th }}$ Month } & $\begin{array}{l}\text { Quarterly: } \\
y_{t-1}^{(2)}, C L I_{t-1}, P A Y_{t}\end{array}$ & \multirow[t]{2}{*}{ October $1^{\text {st }}$} & $\begin{array}{l}\text { Quarterly: } \\
\text { GDP (Q2), CLI (Q2), u (Q2), } \\
\text { PAY (Q3) }\end{array}$ \\
\hline & $\begin{array}{l}\text { Monthly: } \\
y_{\frac{1}{3}(t)}^{(1)}, C L I_{\frac{2}{3}(t)}\end{array}$ & & $\begin{array}{l}\text { Monthly: } \\
\text { GDP (July), CLI (August), u } \\
\text { (August) }\end{array}$ \\
\hline \multirow[t]{2}{*}{$5^{\text {th }}$ Month } & $y_{t-1}^{(3)}, C L I_{t}, P A Y_{t}$ & \multirow[t]{2}{*}{ November $1^{\text {st }}$} & $\begin{array}{l}\text { Quarterly: } \\
\text { GDP (Q2), CLI (Q3), u(Q3), } \\
\text { PAY (Q3) }\end{array}$ \\
\hline & $\begin{array}{l}\text { Monthly: } \\
y_{\frac{2}{3}(t)}^{(1)}, P A Y_{\frac{1}{3}(t+1)}\end{array}$ & & $\begin{array}{l}\text { Monthly: } \\
\text { GDP (August), PAY (October) }\end{array}$ \\
\hline
\end{tabular}


Table 2a: Root Mean Squared Errors, $k=1$, First-Release GDP Growth

\begin{tabular}{l|ccccc}
\hline Model & Month 1 & Month 2 & Month 3 & Month 4 & Month 5 \\
\hline Basecase & 2.41 & 2.25 & 1.70 & 0.98 & 1.02 \\
All Payments & 2.46 & 2.03 & 1.96 & 1.36 & 0.90 \\
Debit \& Credit & 2.28 & 1.79 & 1.77 & 1.30 & 0.86 \\
Credit & 2.31 & 2.21 & 1.89 & 1.14 & 0.85 \\
Debit & 2.29 & 1.88 & 1.55 & 1.00 & 0.83 \\
Cheques & 2.27 & 2.11 & 1.84 & 1.05 & 0.85 \\
\hline
\end{tabular}

Table 2b: Root Mean Squared Errors, $k=4$, First-Release GDP Growth

\begin{tabular}{l|ccccc}
\hline Model & Month 1 & Month 2 & Month 3 & Month 4 & Month 5 \\
\hline Basecase & 1.27 & 1.01 & 0.58 & 0.42 & 0.41 \\
All Payments & 1.40 & 1.03 & 0.65 & 0.43 & 0.35 \\
Debit \& Credit & 1.32 & 0.99 & 0.58 & 0.43 & 0.32 \\
Credit & 1.26 & 1.04 & 0.55 & 0.41 & 0.32 \\
Debit & 1.33 & 0.94 & 0.59 & 0.42 & 0.33 \\
Cheques & 1.24 & 1.05 & 0.60 & 0.40 & 0.34 \\
\hline
\end{tabular}

Table 3a: RMSE Ratios Relative to Basecase $(=1.0), k=1$, First-Release GDP Growth

\begin{tabular}{l|ccccc}
\hline Model & Month 1 & Month 2 & Month 3 & Month 4 & Month 5 \\
\hline Basecase & 1.00 & 1.00 & 1.00 & 1.00 & 1.00 \\
All Payments & 1.02 & 0.90 & 1.16 & 1.39 & 0.88 \\
Debit \& Credit & 0.95 & 0.80 & 1.04 & 1.32 & 0.84 \\
Credit & 0.96 & 0.98 & 1.12 & 1.16 & 0.83 \\
Debit & 0.95 & 0.83 & 0.91 & 1.01 & 0.81 \\
Cheques & 0.94 & 0.94 & 1.08 & 1.07 & 0.83 \\
\hline
\end{tabular}

Table 3b: RMSE Ratios Relative to Basecase $(=1.0), k=4$, First-Release GDP Growth

\begin{tabular}{l|ccccc}
\hline Model & Month 1 & Month 2 & Month 3 & Month 4 & Month 5 \\
\hline Basecase & 1.00 & 1.00 & 1.00 & 1.00 & 1.00 \\
All Payments & 1.10 & 1.02 & 1.12 & 1.01 & 0.84 \\
Debit \& Credit & 1.02 & 0.98 & 1.00 & 1.04 & 0.78 \\
Credit & 0.99 & 1.03 & 0.96 & 0.99 & 0.79 \\
Debit & 1.04 & 0.93 & 1.02 & 1.01 & 0.81 \\
Cheques & 0.98 & 1.04 & 1.04 & 0.96 & 0.83 \\
\hline
\end{tabular}


Figure 1a: Average Credit, Debit and Cheque Transactions (\$)

Credit and Debit: Left Scale; Cheque: Right Scale

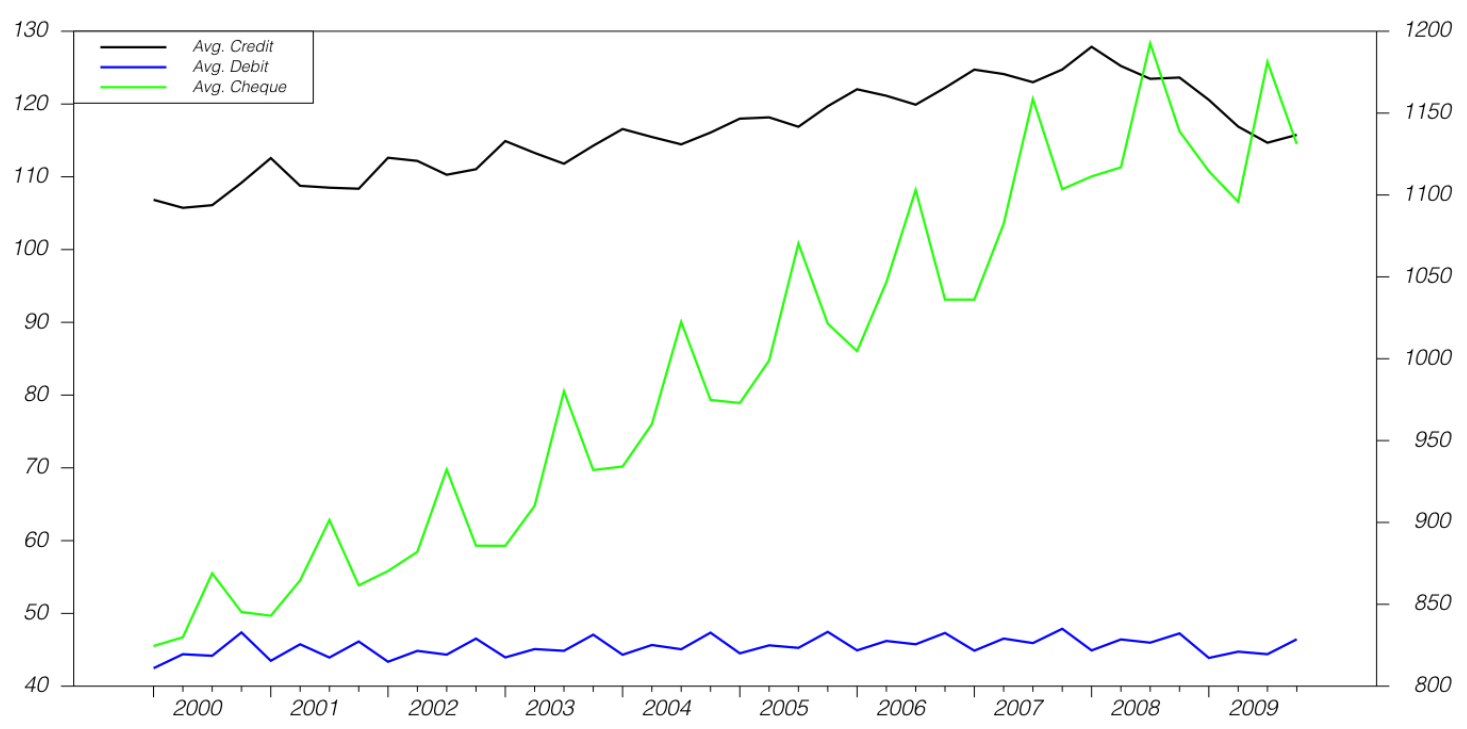

Figure 1b:

Joint density surface plot

debit volume vs. average value per transaction

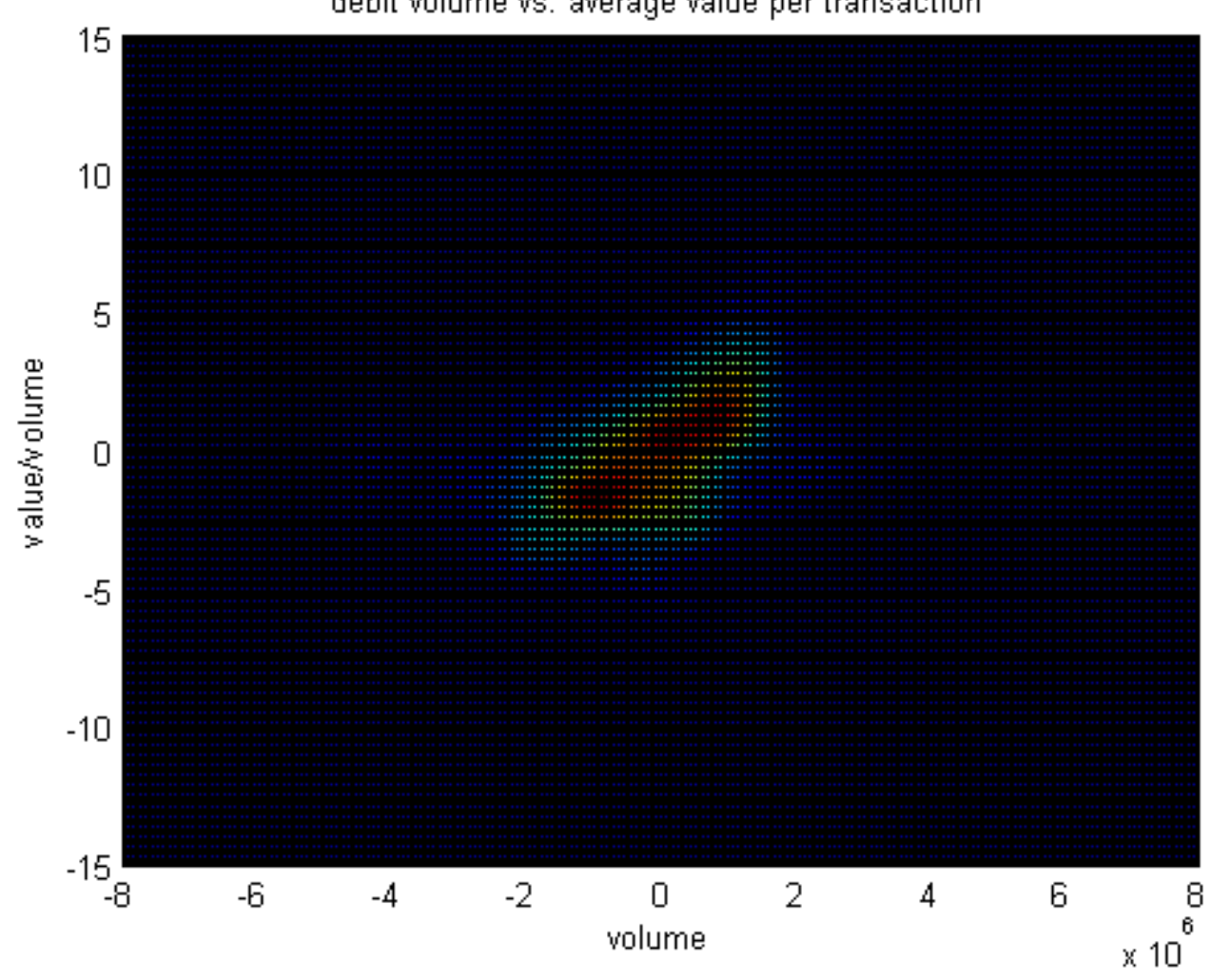


Figure 1c:

Joint density surface plot

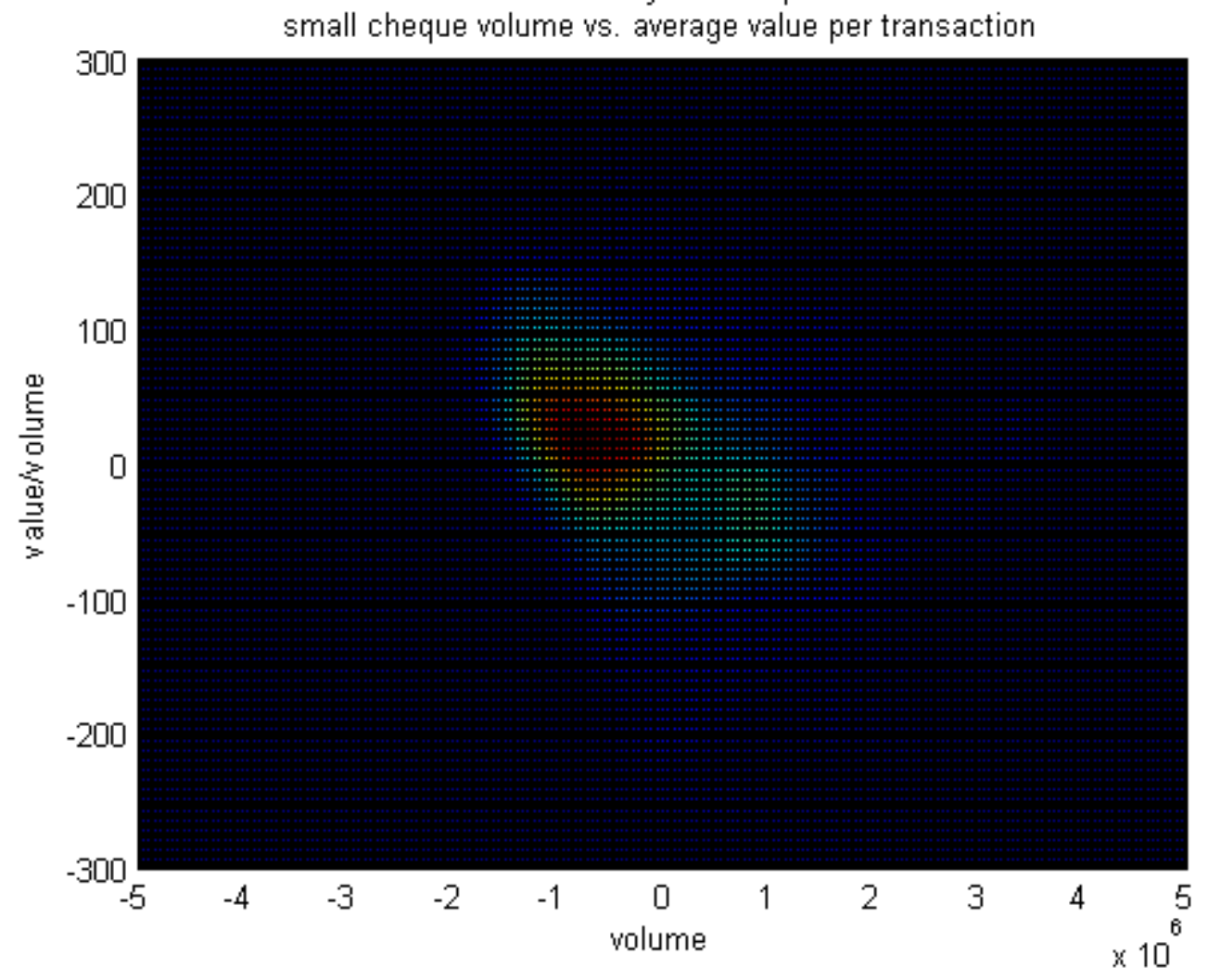




\section{Figure 1d:}

Joint density surface plot

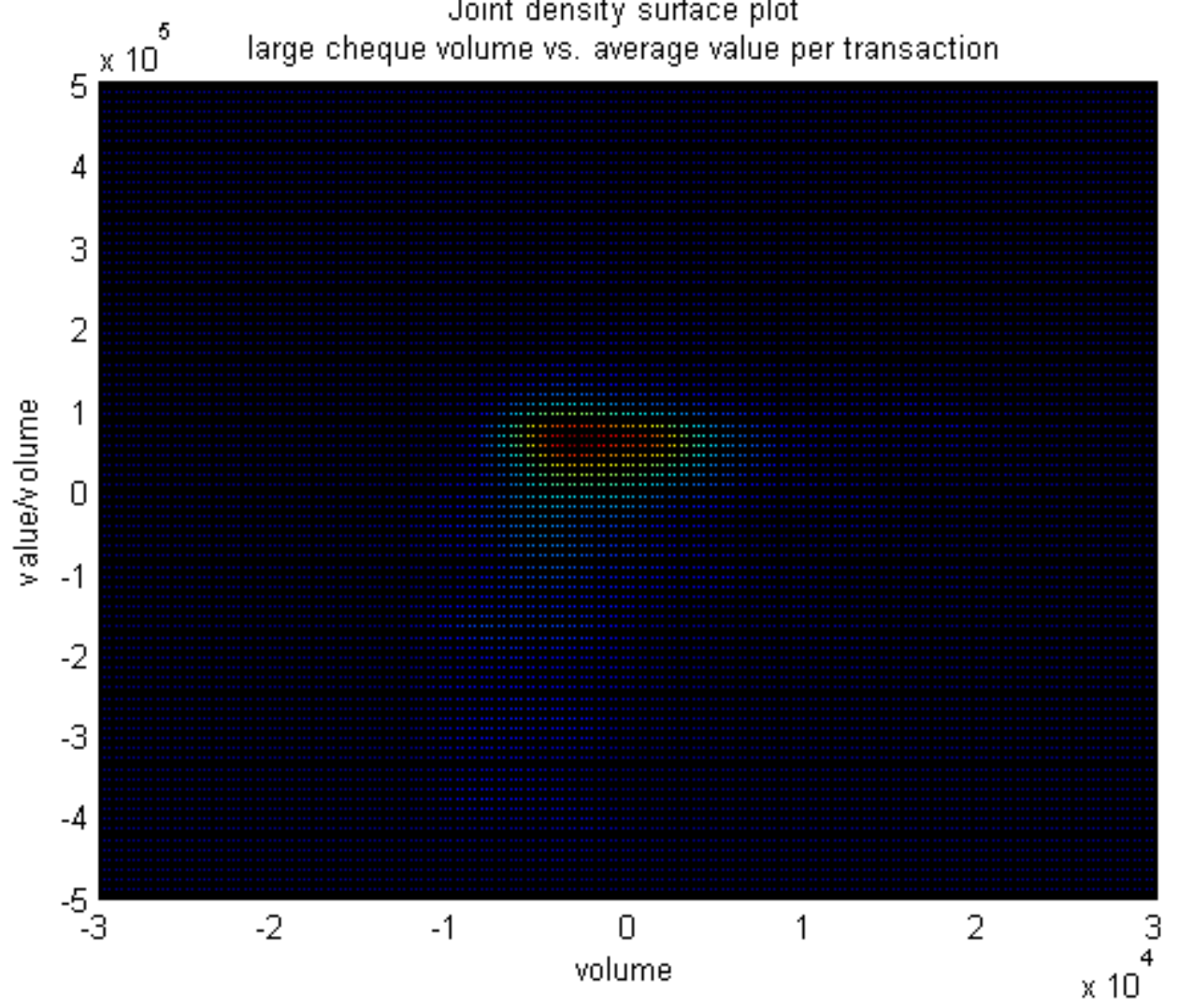


Figure 2a: Growth Rates $(k=1)$ of Average Credit, Debit and Cheque Transactions

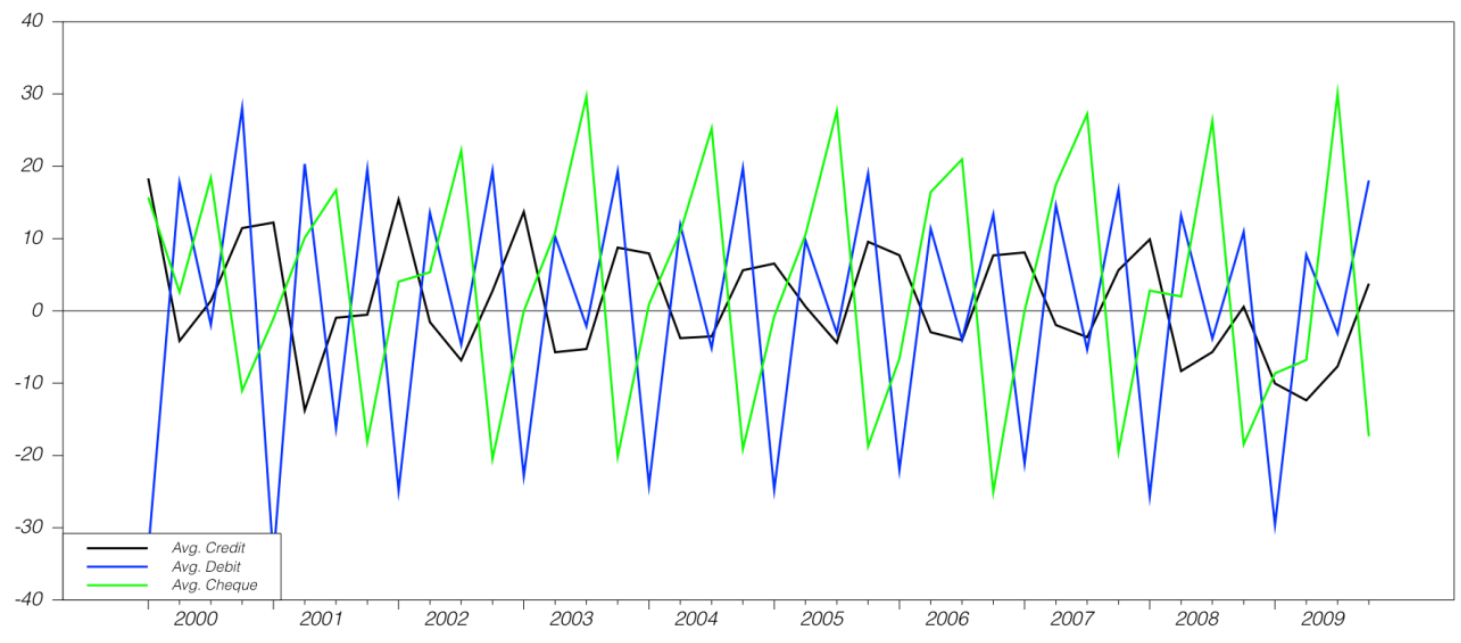

Figure 2b: Growth Rates $(k=4)$ of Average Credit, Debit and Cheque Transactions

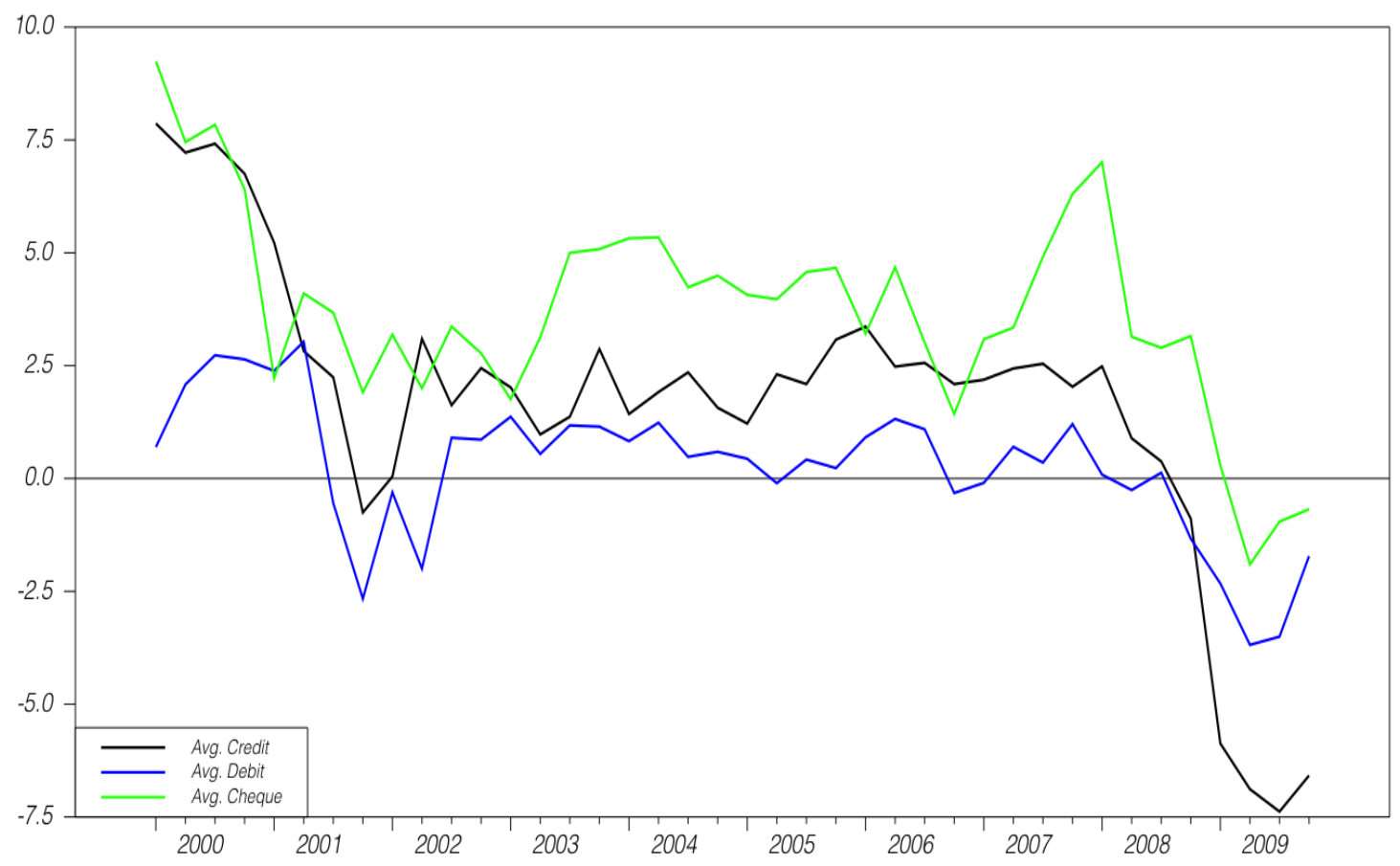


Figure 3a: Growth Rate $(k=1)$, Credit Card Transaction Values, NSA and SA

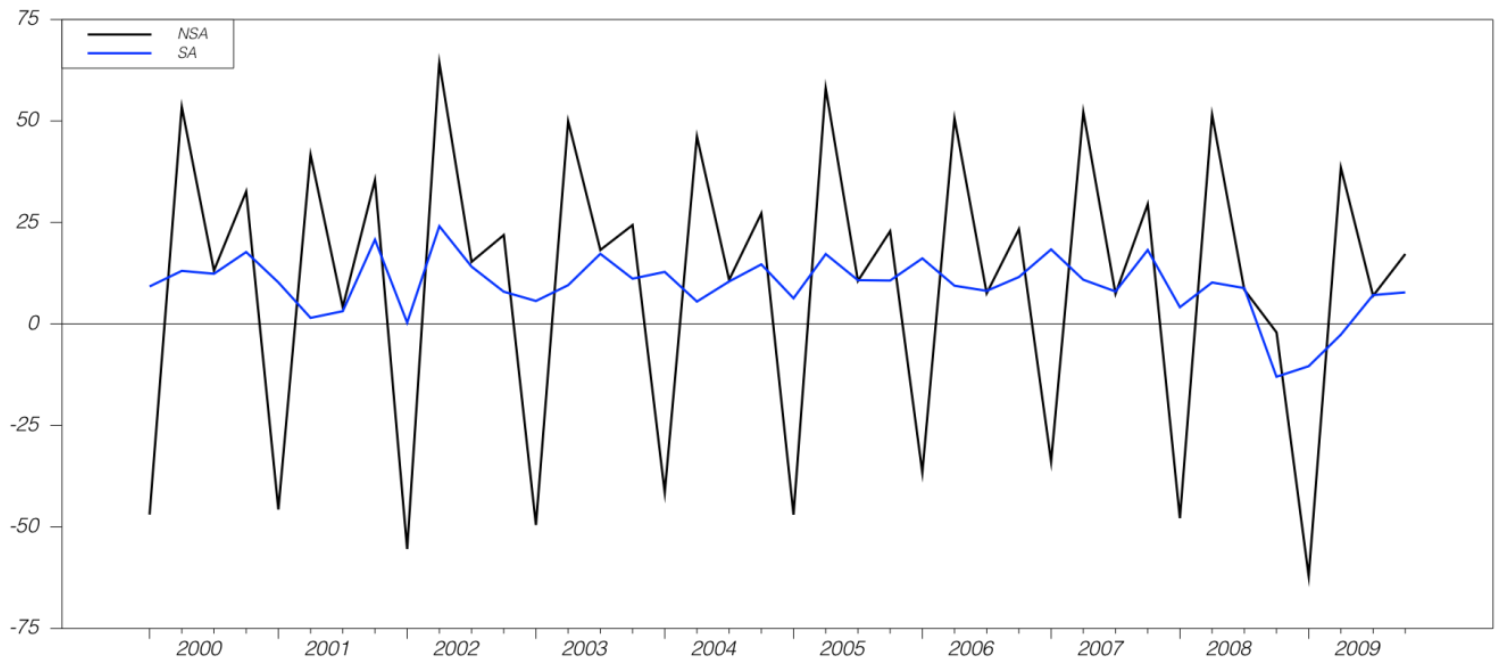

Figure 3b: Growth Rate $(k=4)$, Credit Card Transaction Values, NSA and SA

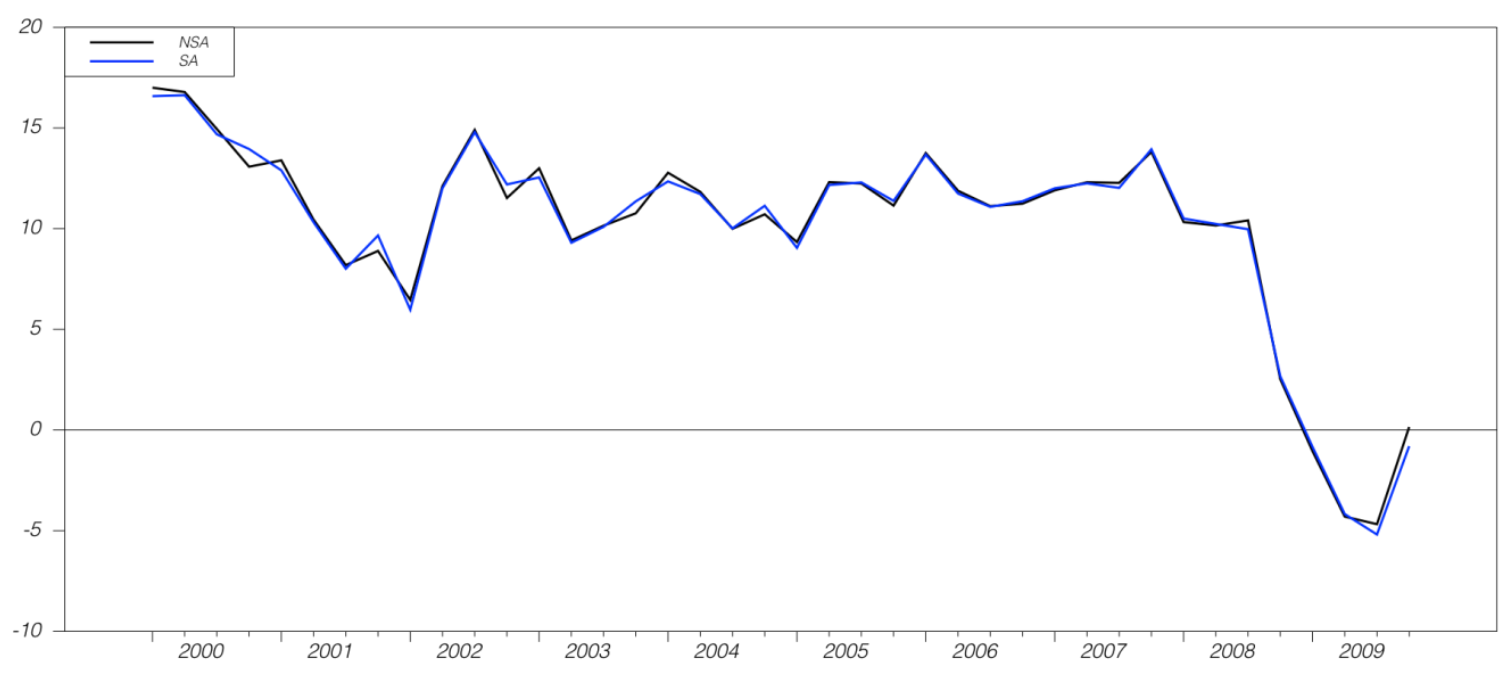


Figure 4a: Growth Rate $(k=1)$ Composite Leading Index

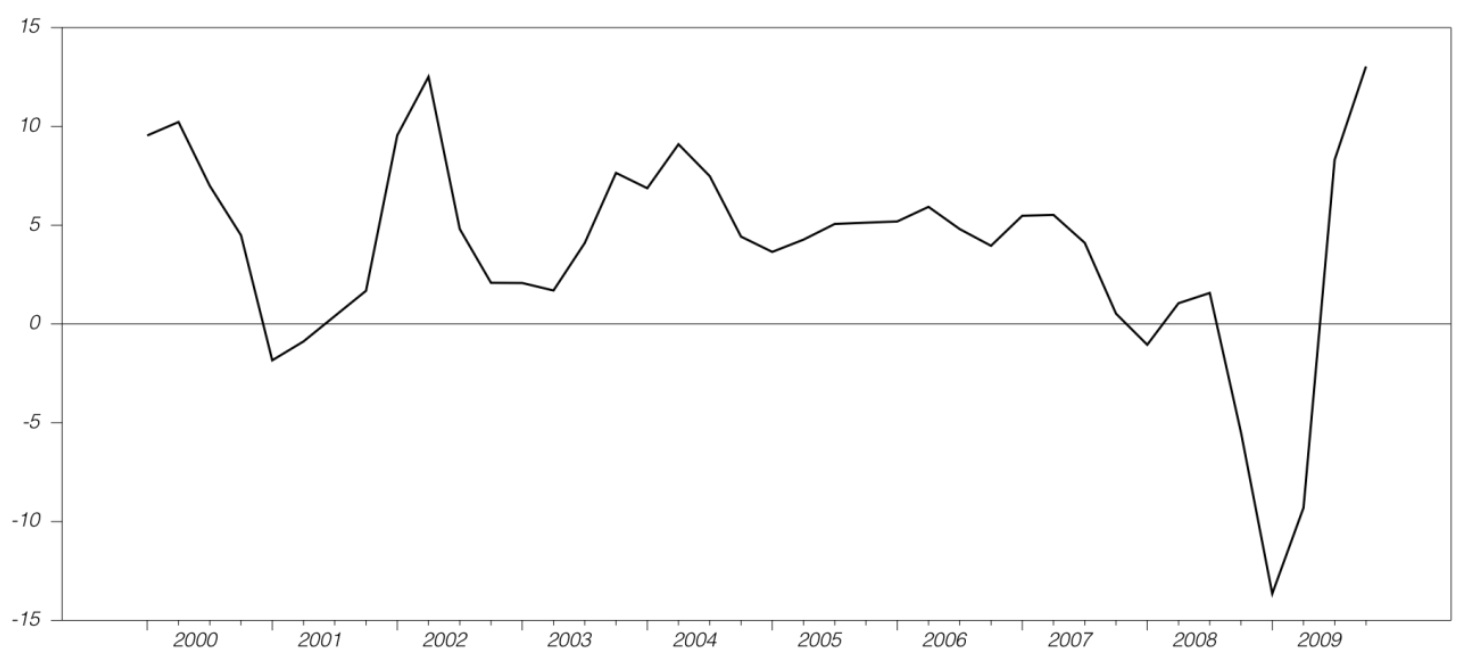

Figure 4b: Growth Rate ( $k=4)$ Composite Leading Index

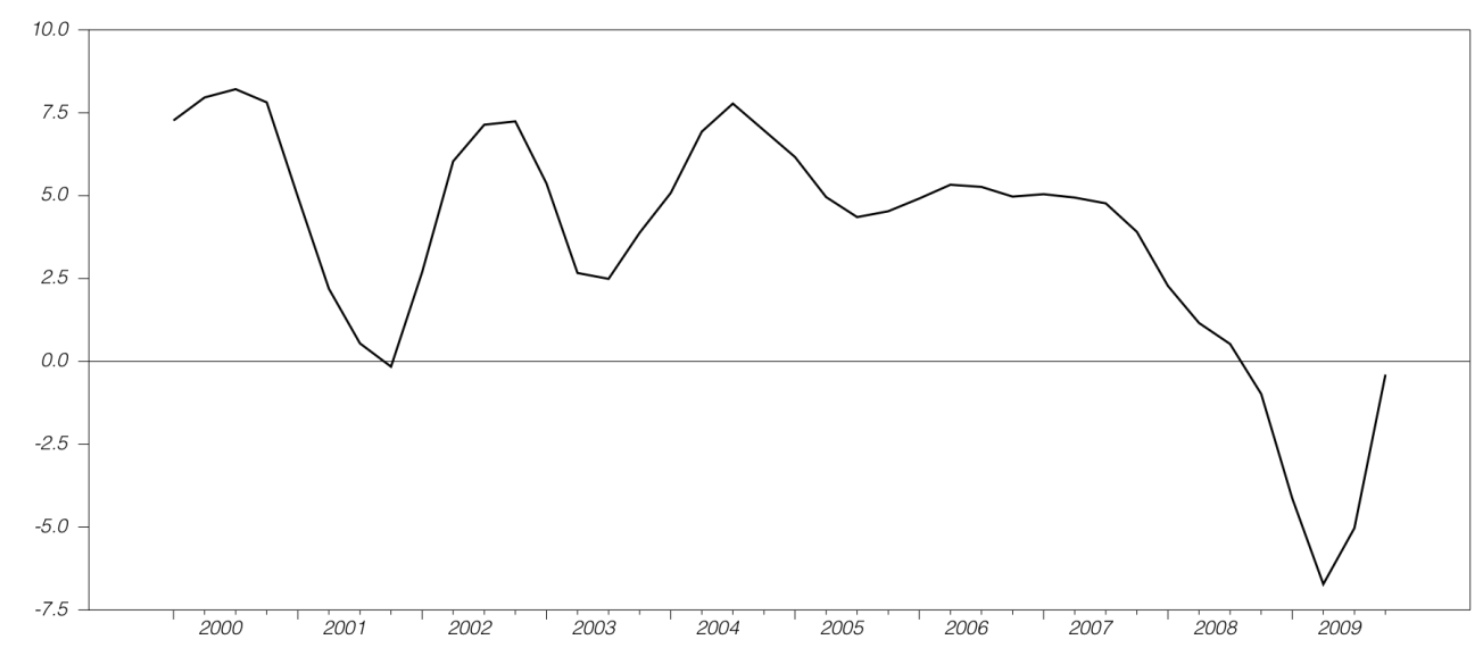


Figure 5a: GDP Growth $(k=1)$, First Release and 2009Q4 Vintage

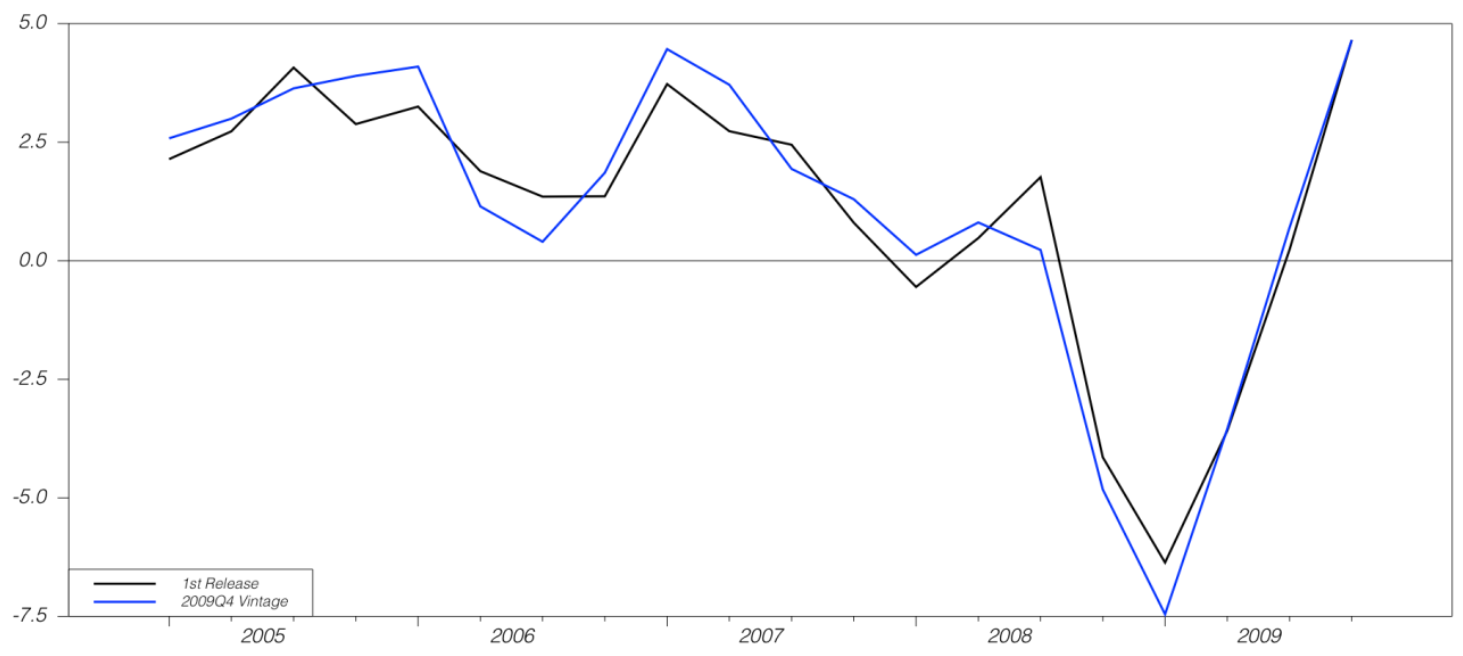

Figure 5b: GDP Growth $(k=4)$, First Release and 2009Q4 Vintage

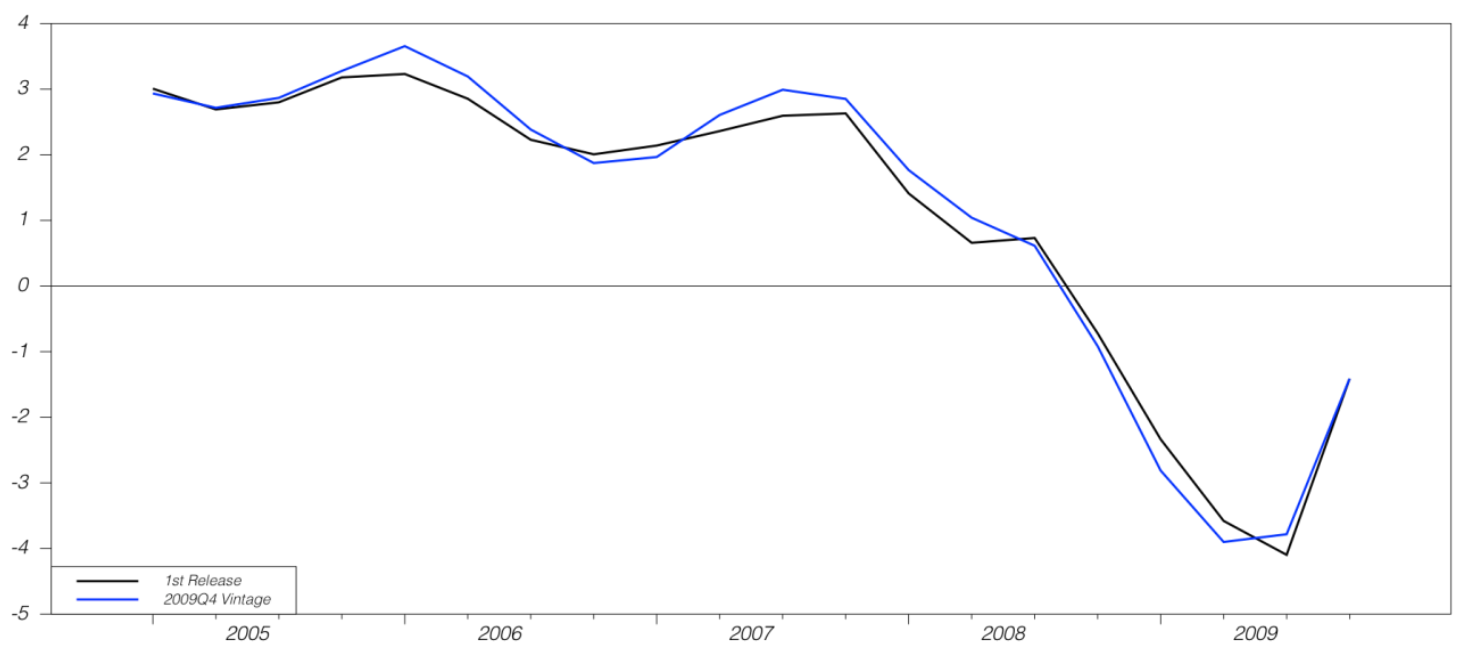


Figure 6a: GDP Growth $(k=1)$ Basecase Nowcasts

Produced at Different Points in Time

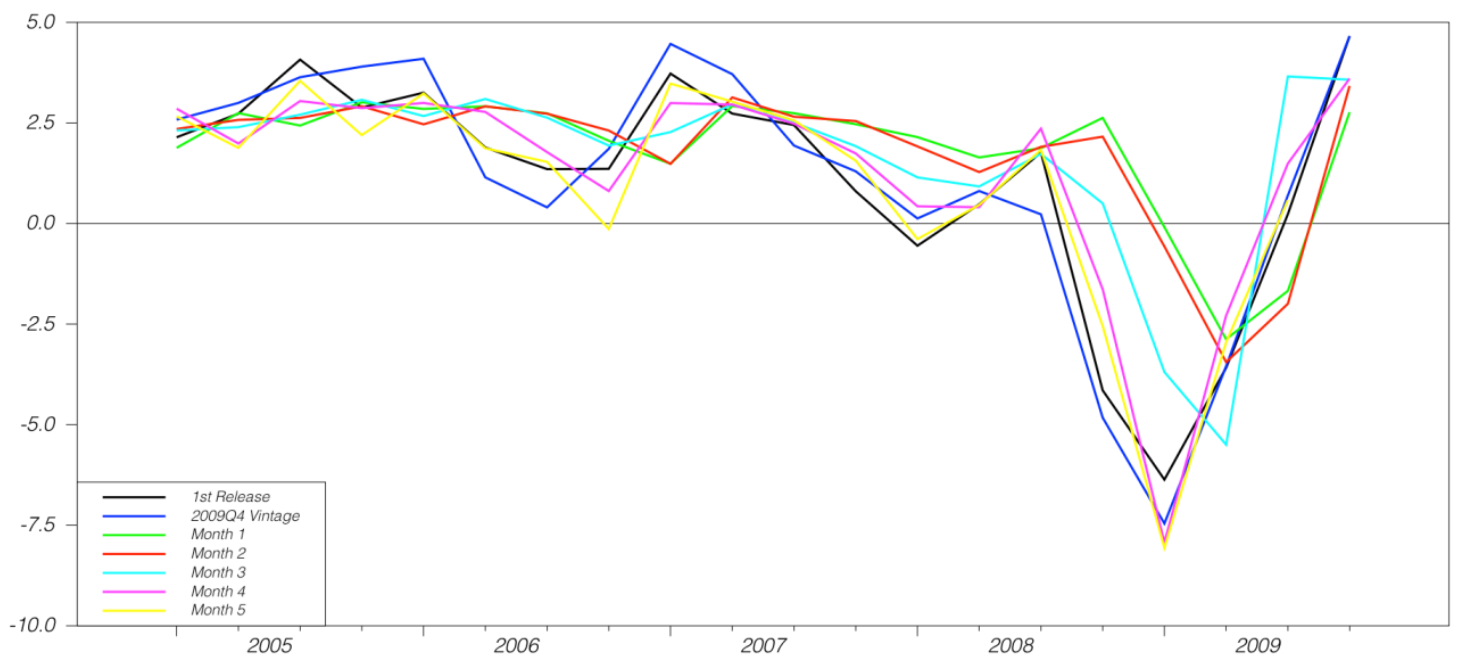

Figure 6b: GDP Growth $(k=4)$ Basecase Nowcasts

Produced at Different Points in Time

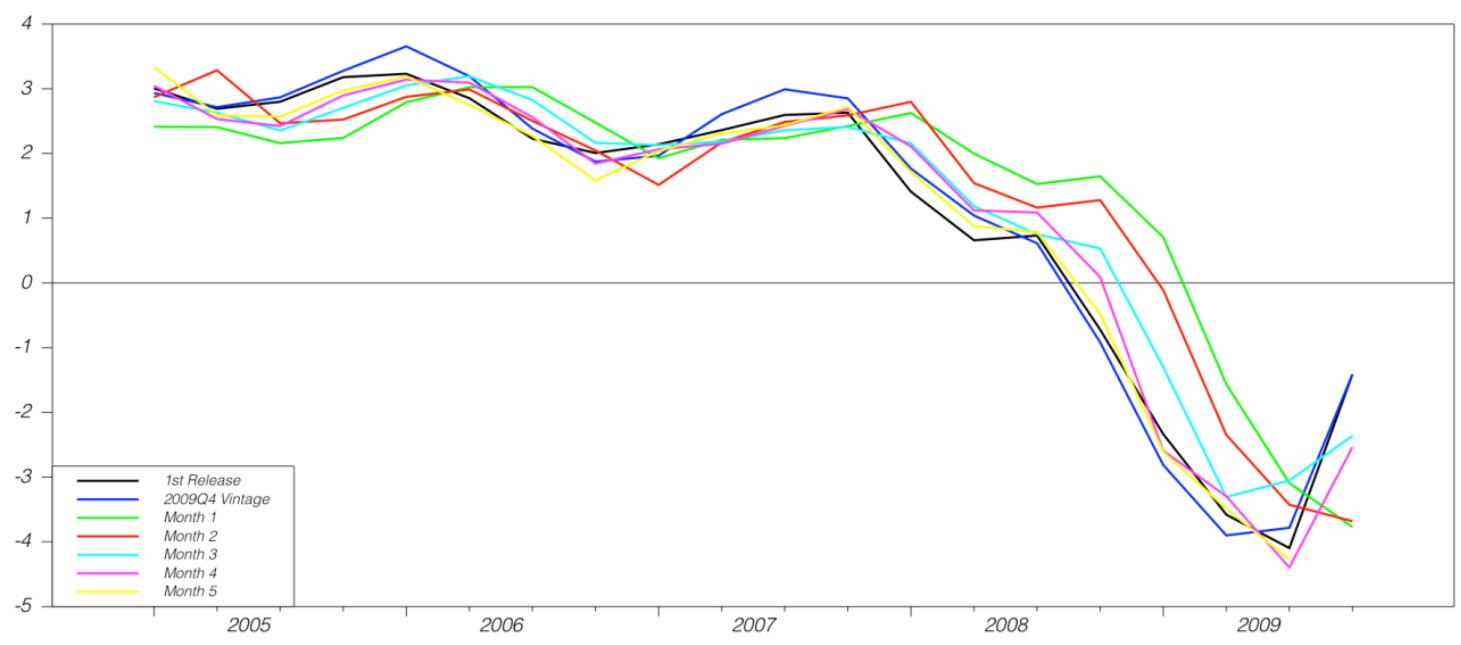


Figure 7a: GDP Growth $(k=1)$ Nowcasts Using Debit Transactions Produced at Different Points in Time

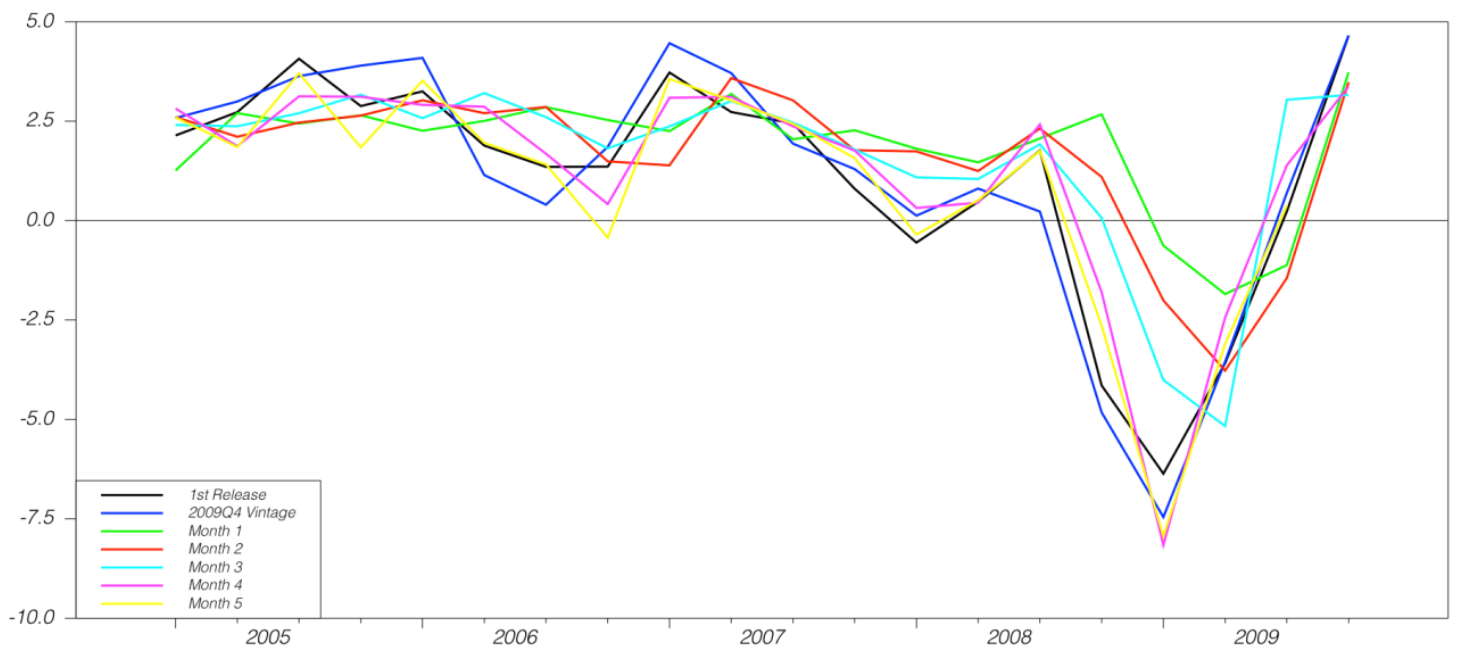

Figure 7b: GDP Growth $(k=4)$ Nowcasts Using Debit Transactions Produced at Different Points in Time

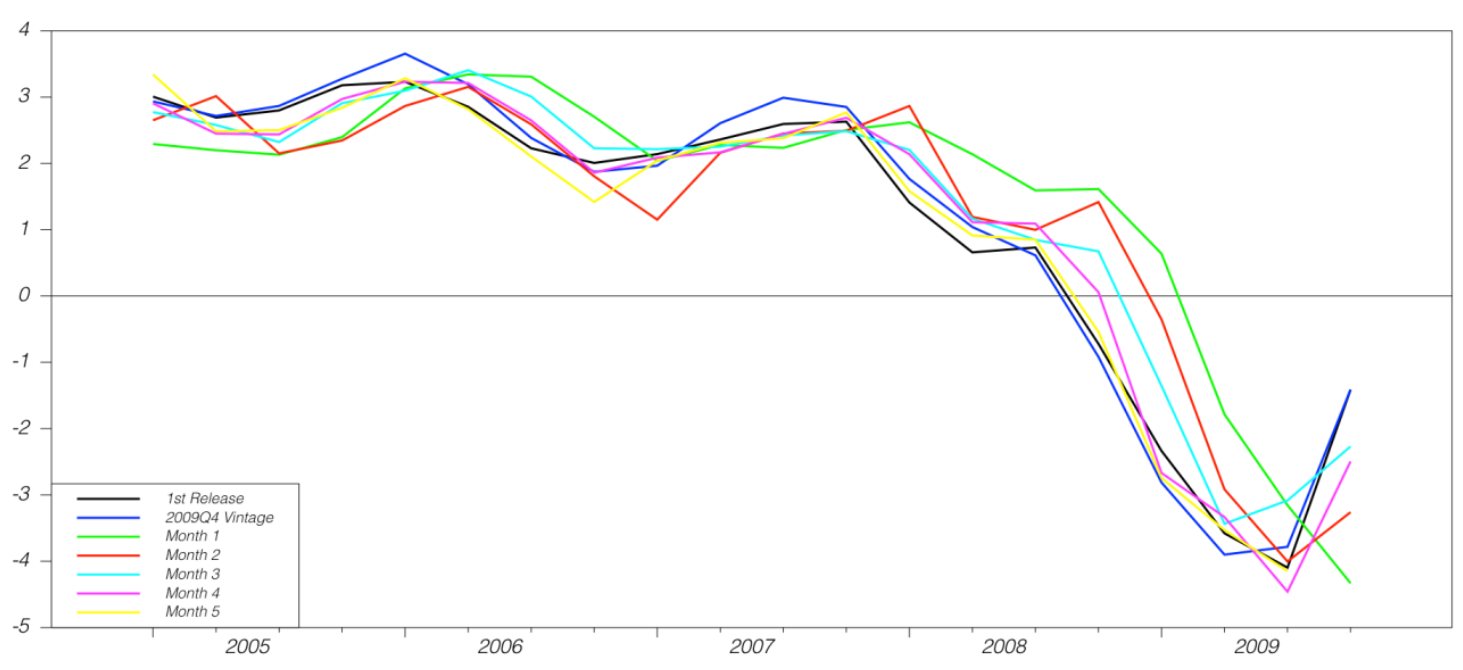


Figure 8a: GDP Growth $(k=1)$ Nowcast RMSEs by Month of Nowcast Production

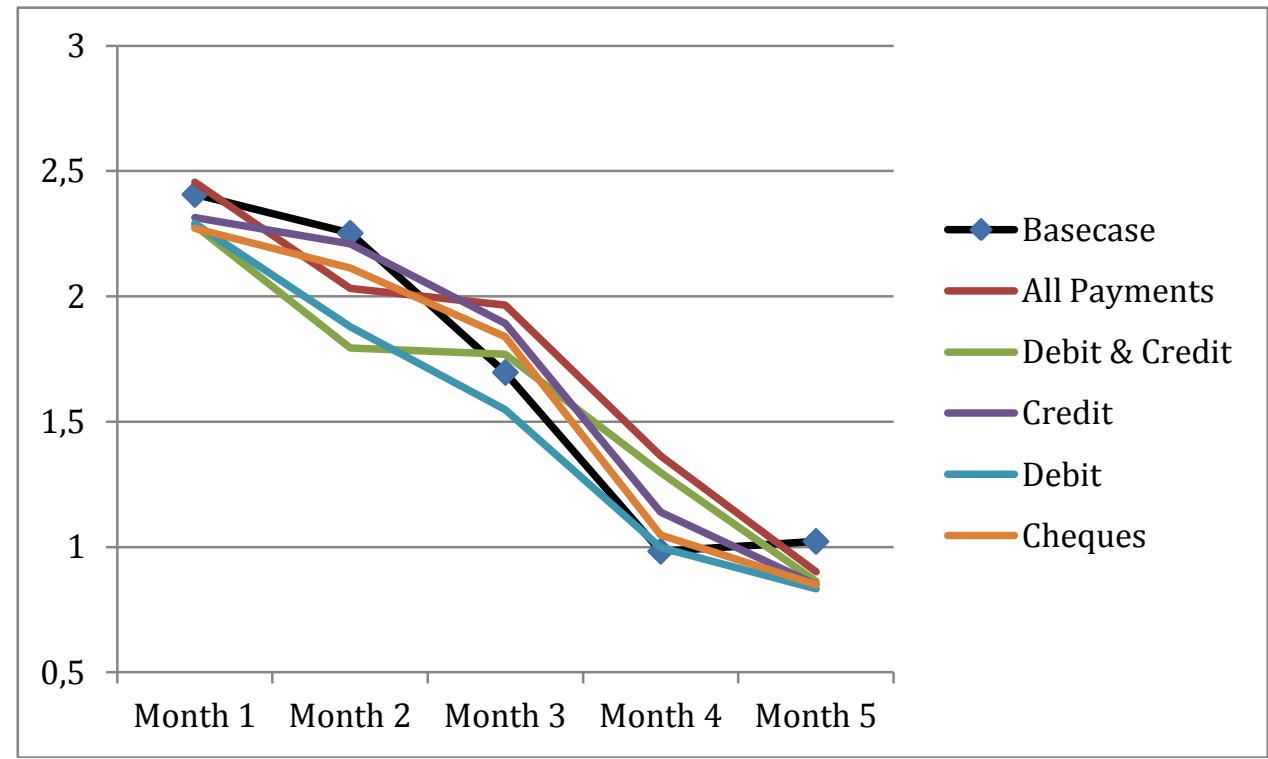

Figure 8b: GDP Growth $(k=4)$ Nowcast RMSEs by Month of Nowcast Production

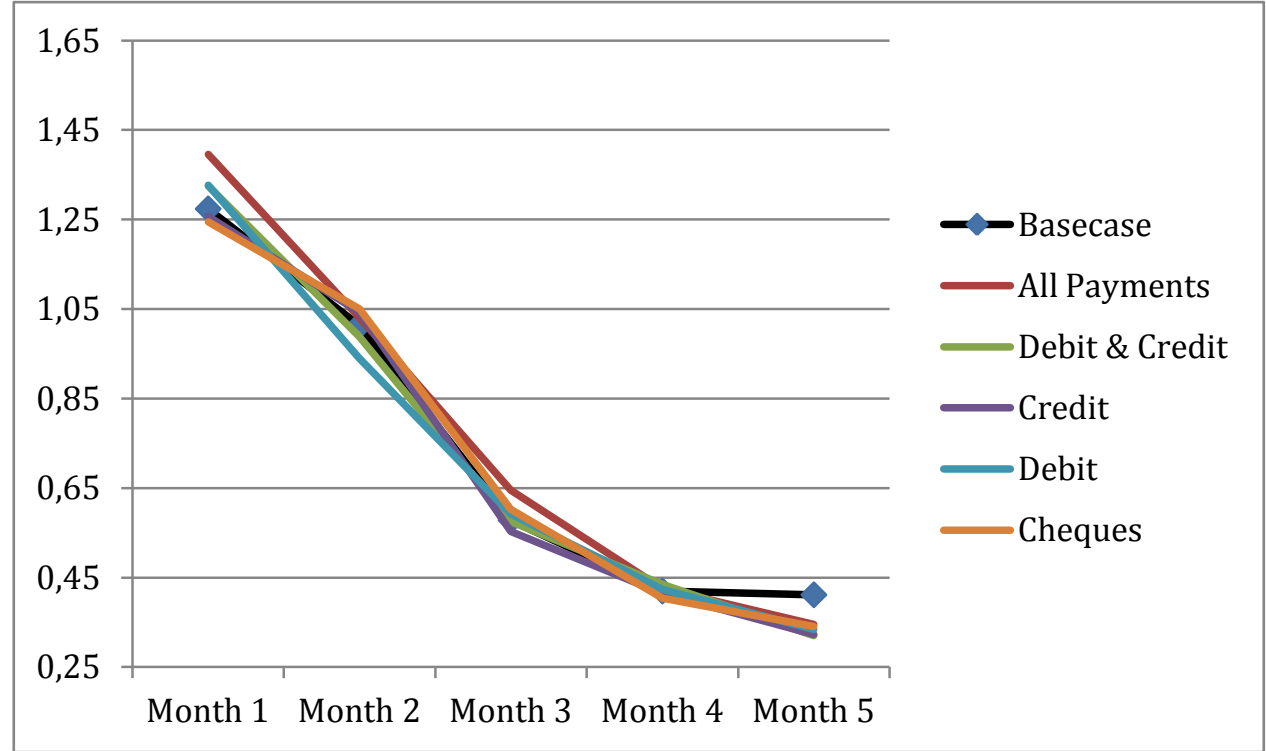


Figure 9a: GDP Growth $(k=1)$ Nowcast RMSE Ratios Relative to Basecase (=1.0) By Month of Nowcast Production

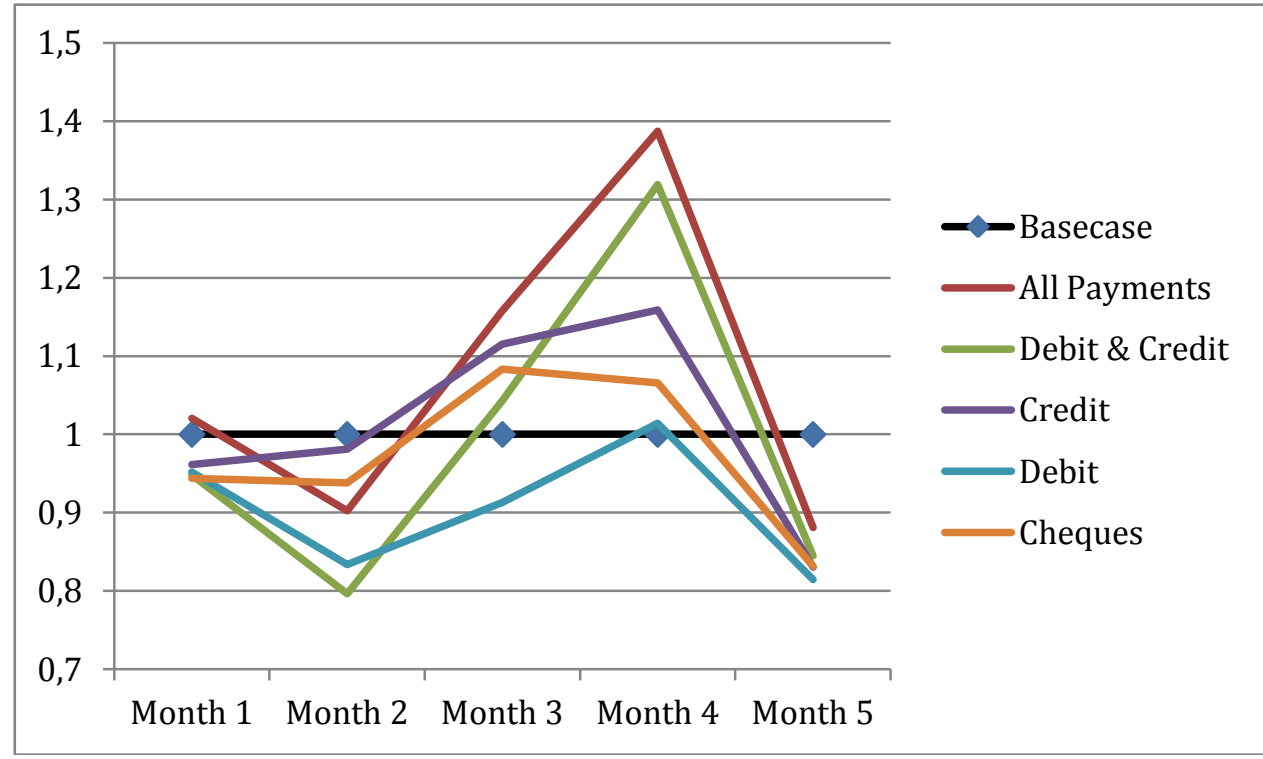

Figure 9b: GDP Growth $(k=4)$ Nowcast RMSE Ratios Relative to Basecase $(=1.0)$ By Month of Nowcast Production

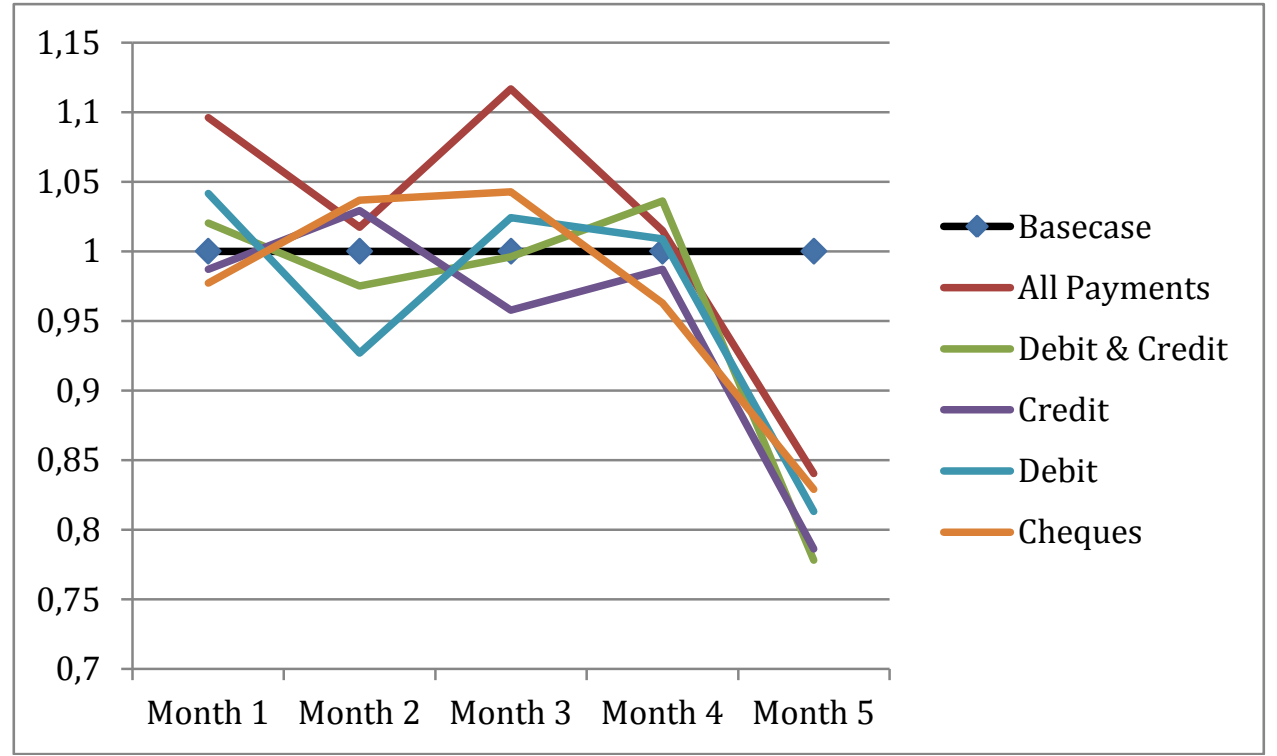




\section{Appendix: supplementary results}

\section{RMSEs Computed Relative to "Final” (i.e. 2009Q4) GDP Vintage}

Table 4a: Root Mean Squared Errors, $k=1,2009 Q 4$ Vintage GDP Growth

\begin{tabular}{l|ccccc}
\hline Model & Month 1 & Month 2 & Month 3 & Month 4 & Month 5 \\
\hline Basecase & 2.75 & 2.61 & 1.98 & 1.25 & 1.12 \\
All Payments & 2.71 & 2.42 & 2.29 & 1.56 & 1.12 \\
Debit \& Credit & 2.62 & 2.16 & 2.11 & 1.52 & 1.09 \\
Credit & 2.68 & 2.54 & 2.20 & 1.38 & 1.07 \\
Debit & 2.64 & 2.26 & 1.85 & 1.24 & 1.13 \\
Cheques & 2.66 & 2.41 & 2.14 & 1.29 & 1.11 \\
\hline
\end{tabular}

Table 4b: Root Mean Squared Errors, k = 4, 2009Q4 Vintage GDP Growth

\begin{tabular}{l|ccccc}
\hline Model & Month 1 & Month 2 & Month 3 & Month 4 & Month 5 \\
\hline Basecase & 1.37 & 1.09 & 0.65 & 0.48 & 0.40 \\
All Payments & 1.45 & 1.08 & 0.64 & 0.43 & 0.36 \\
Debit \& Credit & 1.40 & 1.07 & 0.60 & 0.47 & 0.35 \\
Credit & 1.35 & 1.13 & 0.61 & 0.46 & 0.37 \\
Debit & 1.40 & 1.02 & 0.65 & 0.47 & 0.41 \\
Cheques & 1.31 & 1.11 & 0.65 & 0.42 & 0.40 \\
\hline
\end{tabular}

Table 5a: RMSE Ratios Relative to Basecase $(=1.0), k=1,2009 Q 4$ Vintage GDP Growth

\begin{tabular}{l|ccccc}
\hline Model & Month 1 & Month 2 & Month 3 & Month 4 & Month 5 \\
\hline Basecase & 1.00 & 1.00 & 1.00 & 1.00 & 1.00 \\
All Payments & 0.98 & 0.93 & 1.16 & 1.25 & 1.00 \\
Debit \& Credit & 0.95 & 0.83 & 1.06 & 1.22 & 0.97 \\
Credit & 0.97 & 0.97 & 1.11 & 1.10 & 0.95 \\
Debit & 0.96 & 0.87 & 0.94 & 1.00 & 1.01 \\
Cheques & 0.97 & 0.93 & 1.08 & 1.03 & 0.99 \\
\hline
\end{tabular}

Table 5b: RMSE Ratios Relative to Basecase $(=1.0), k=4,2009$ Q4 Vintage GDP Growth

\begin{tabular}{l|ccccc}
\hline Model & Month 1 & Month 2 & Month 3 & Month 4 & Month 5 \\
\hline Basecase & 1.00 & 1.00 & 1.00 & 1.00 & 1.00 \\
All Payments & 1.06 & 0.99 & 0.99 & 0.89 & 0.91 \\
Debit \& Credit & 1.02 & 0.98 & 0.92 & 0.97 & 0.89 \\
Credit & 0.98 & 1.03 & 0.94 & 0.96 & 0.93 \\
Debit & 1.02 & 0.93 & 1.00 & 0.97 & 1.03 \\
Cheques & 0.96 & 1.02 & 1.00 & 0.87 & 1.01 \\
\hline
\end{tabular}


Figure 10a: GDP Growth $(k=1)$ Nowcast RMSEs for 2009Q4 GDP Vintage by Month of Nowcast Production

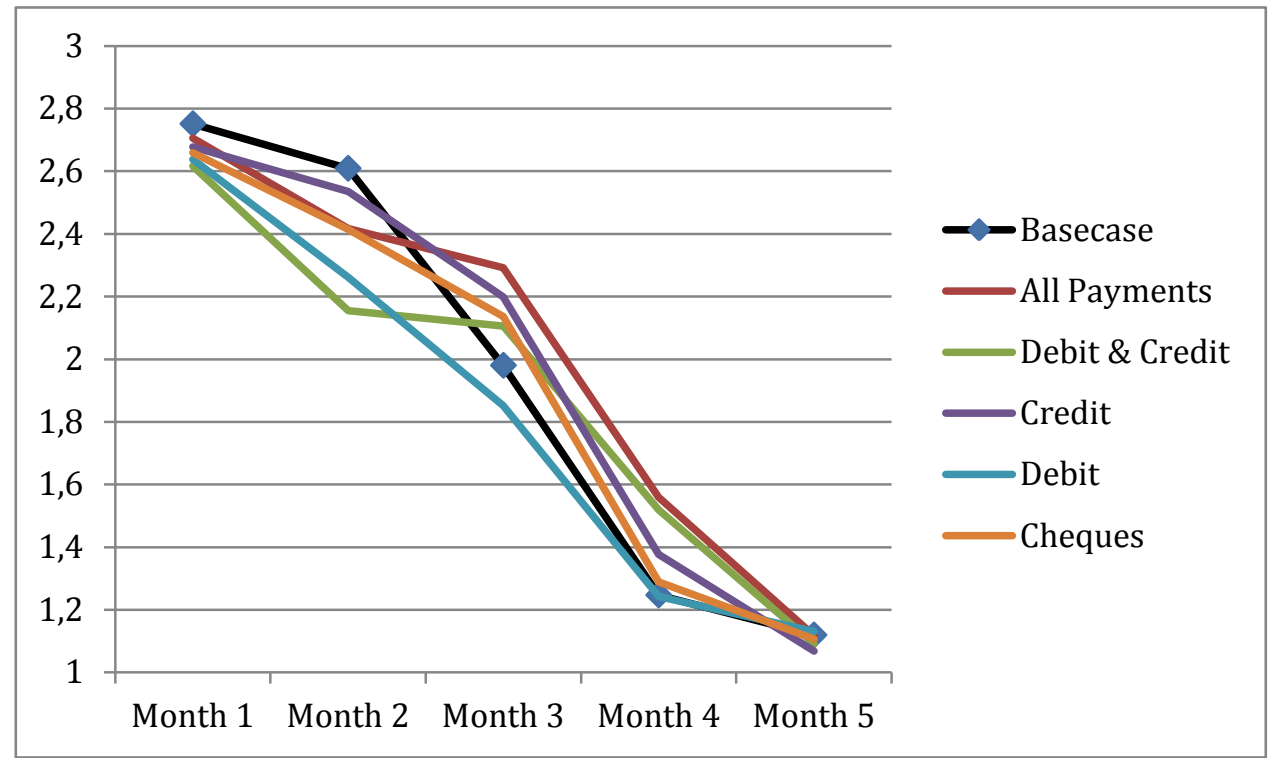

Figure 10b: GDP Growth $(k=4)$ Nowcast RMSEs for 2009Q4 GDP Vintage by Month of Nowcast Production

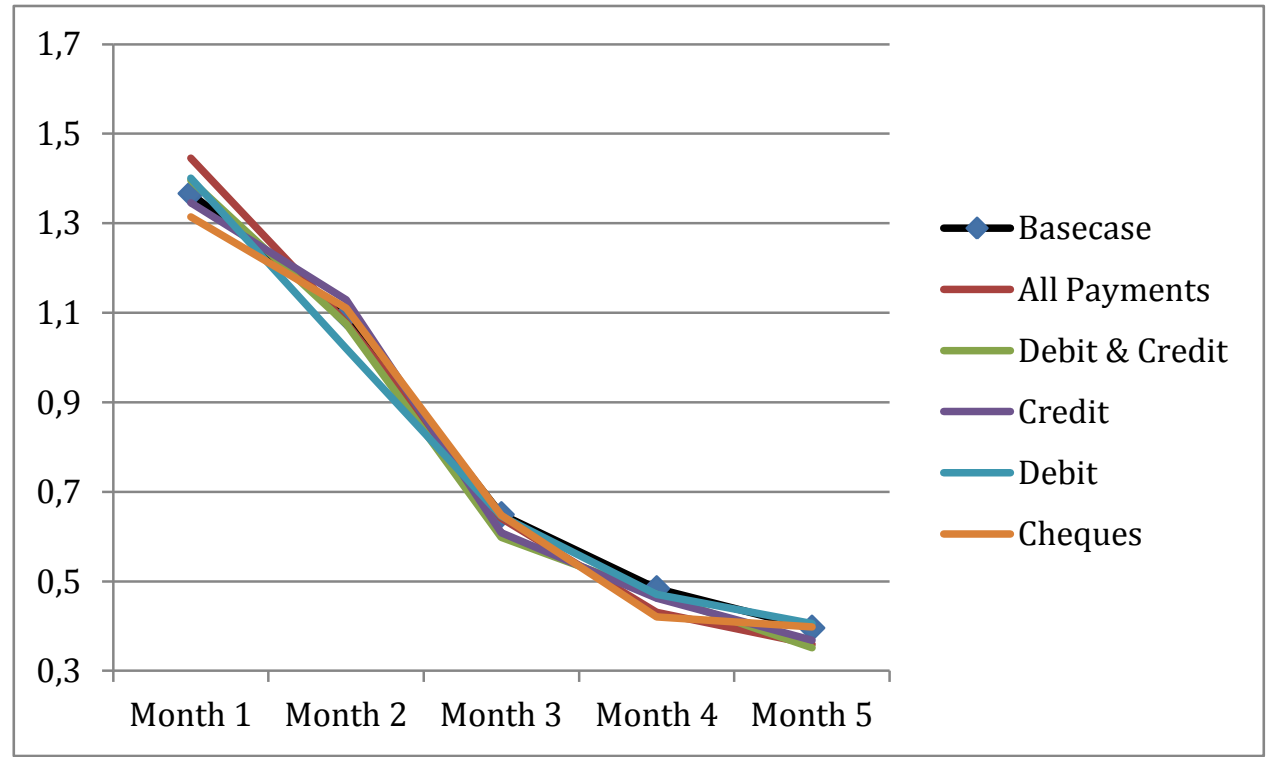


Figure 11a: GDP Growth $(k=1)$ Nowcast RMSE Ratios Relative to Basecase (=1.0) for 2009Q4 GDP Vintage, By Month of Nowcast Production

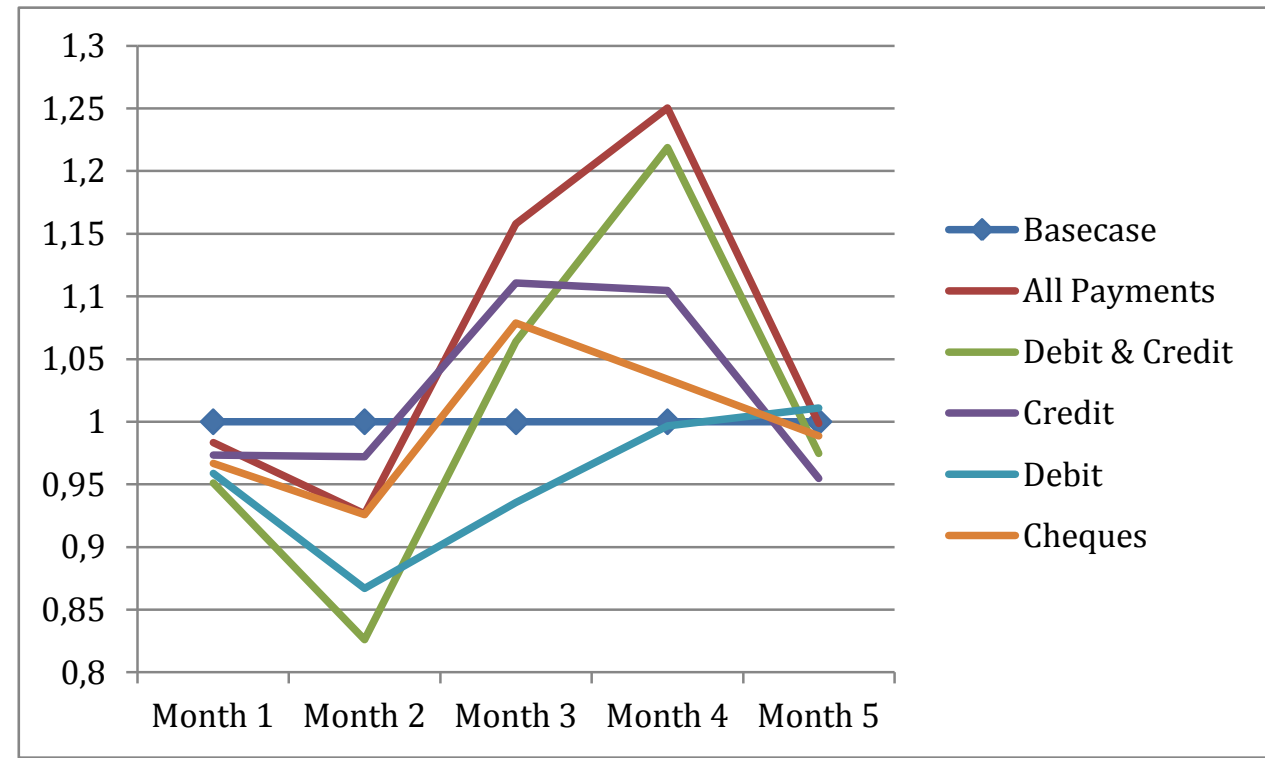

Figure 11b: GDP Growth $(k=4)$ Nowcast RMSE Ratios Relative to Basecase (=1.0) for 2009Q4 GDP Vintage, By Month of Nowcast Production

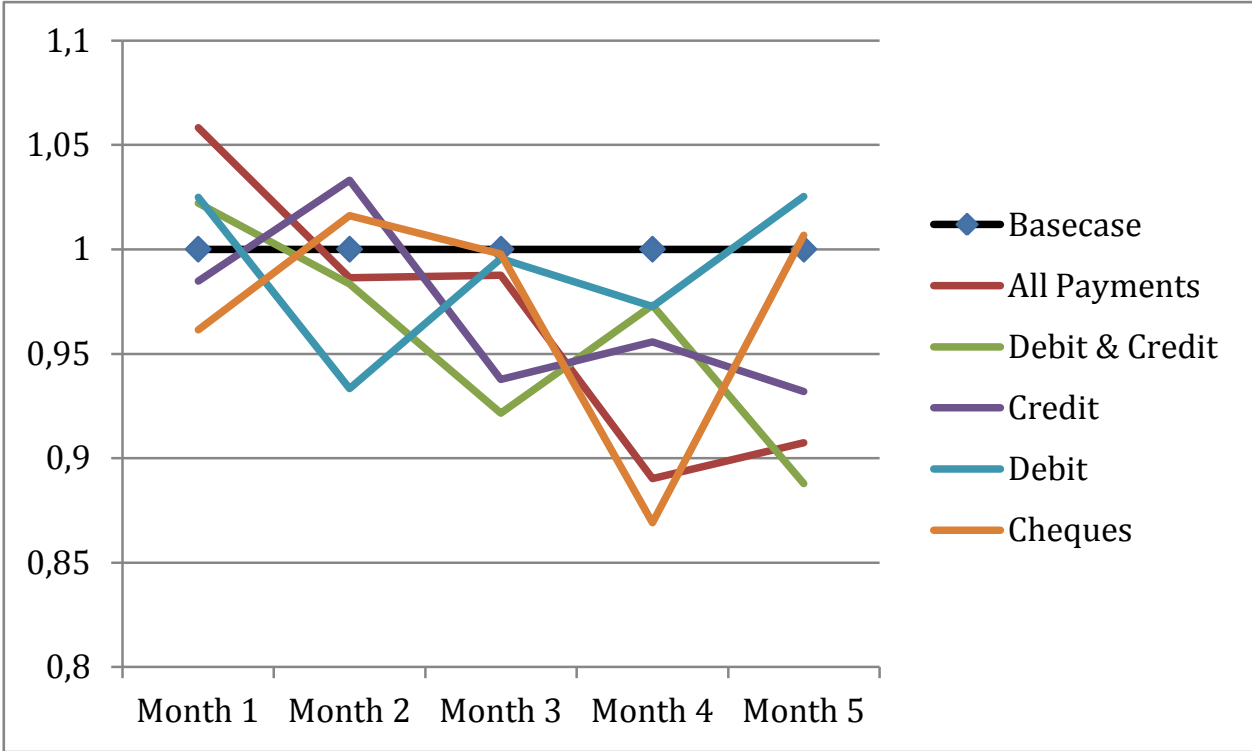

